\title{
Temporal and spatial characteristics of ozone depletion events from measurements in the Arctic
}

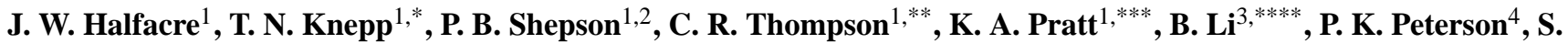 \\ J. Walsh ${ }^{4}$, W. R. Simpson ${ }^{4}$, P. A. Matrai ${ }^{5}$, J. W. Bottenheim ${ }^{6}$, S. Netcheva ${ }^{7}$, D. K. Perovich ${ }^{8}$, and A. Richter ${ }^{9}$ \\ ${ }^{1}$ Department of Chemistry, Purdue University, West Lafayette, Indiana, USA \\ ${ }^{2}$ Department of Earth, Atmospheric, and Planetary Sciences, Purdue University, West Lafayette, Indiana, USA \\ ${ }^{3}$ Department of Statistics, Purdue University, West Lafayette, Indiana, USA \\ ${ }^{4}$ Department of Chemistry, University of Alaska, Fairbanks, Alaska, USA \\ ${ }^{5}$ Bigelow Laboratory for Ocean Sciences, East Boothbay, Maine, USA \\ ${ }^{6}$ Air Quality Research Division, Environment Canada, Toronto, Ontario, Canada \\ ${ }^{7}$ Air Quality Processes Research Section, Environment Canada, Toronto, Ontario, Canada \\ ${ }^{8}$ US Army Cold Regions Research and Engineering Laboratory, Fairbanks, Alaska, USA \\ ${ }^{9}$ Institute of Environmental Physics, University of Bremen, Bremen, Germany \\ *now at: Science Systems and Applications, Inc., Hampton, Virginia, USA \\ ** now at: Institute of Arctic and Alpine Research, University of Colorado at Boulder, Boulder, Colorado, USA \\ *** now at: Department of Chemistry, University of Michigan, Ann Arbor, Michigan, USA \\ **** now at: Department of Statistics, University Illinois at Urbana-Champaign, Urbana, Illinois, USA
}

Correspondence to: J. W. Halfacre (jhalfacr@purdue.edu)

Received: 9 October 2013 - Published in Atmos. Chem. Phys. Discuss.: 19 November 2013

Revised: 24 February 2014 - Accepted: 21 March 2014 - Published: 20 May 2014

\begin{abstract}
Following polar sunrise in the Arctic springtime, tropospheric ozone episodically decreases rapidly to nearzero levels during ozone depletion events (ODEs). Many uncertainties remain in our understanding of ODE characteristics, including the temporal and spatial scales, as well as environmental drivers. Measurements of ozone, bromine monoxide (BrO), and meteorology were obtained during several deployments of autonomous, ice-tethered buoys (OBuoys) from both coastal sites and over the Arctic Ocean; these data were used to characterize observed ODEs. Detected decreases in surface ozone levels during the onset of ODEs corresponded to a median estimated apparent ozone depletion timescale (based on both chemistry and the advection of $\mathrm{O}_{3}$-depleted air) of $11 \mathrm{~h}$. If assumed to be dominated by chemical mechanisms, these timescales would correspond to larger-than-observed $\mathrm{BrO}$ mole fractions based on known chemistry and assumed other radical levels. Using backward air mass trajectories and an assumption that transport mechanisms dominate observations, the spatial scales for ODEs (defined by time periods in which ozone lev-
\end{abstract}

els $\leq 15 \mathrm{nmol} \mathrm{mol}^{-1}$ ) were estimated to be $877 \mathrm{~km}$ (median), while areas estimated to represent major ozone depletions $\left(<10 \mathrm{nmol} \mathrm{mol}^{-1}\right)$ had dimensions of $282 \mathrm{~km}$ (median). These observations point to a heterogeneous boundary layer with localized regions of active, ozone-destroying halogen chemistry, interspersed among larger regions of previously depleted air that retain reduced ozone levels through hindered atmospheric mixing. Based on the estimated size distribution, Monte Carlo simulations showed it was statistically possible that all ODEs observed could have originated upwind, followed by transport to the measurement site. Local wind speed averages were low during most ODEs (median of $\sim 3.6 \mathrm{~m} \mathrm{~s}^{-1}$ ), and there was no apparent dependence on local temperature. 


\section{Introduction}

Global tropospheric oxidation is generally controlled by ozone $\left(\mathrm{O}_{3}\right)$, a major greenhouse gas (Gauss et al., 2006) and the most important precursor to the primary atmospheric oxidant, hydroxyl radical (OH) (Seinfeld and Pandis, 2006; Thompson, 1992). When the sun rises in the Arctic springtime (typically around mid-March), boundary layer $\mathrm{O}_{3}$ often drops precipitously from background mole fractions of $\sim 40 \mathrm{nmol} \mathrm{mol}^{-1}$ (ppbv, parts per billion by volume) to near zero levels for periods of hours, or even days, before recovering (Anlauf et al., 1994; Barrie et al., 1988; Bottenheim et al., 1986, 2002). During these ozone depletion events (ODEs), the prominent regional tropospheric oxidation pathways for hydrocarbons at the surface are driven by species other than $\mathrm{OH}$ radicals, notably $\mathrm{Cl}$ and $\mathrm{Br}$ atoms (Cavender et al., 2008; Jobson et al., 1994).

ODEs are considered to start by the reaction of $\mathrm{O}_{3}$ with photolytically active halogens, particularly bromine (R1, R2) (Simpson et al., 2007b).

$$
\begin{aligned}
& \mathrm{Br}_{2}+h v \longrightarrow 2 \mathrm{Br} \\
& \mathrm{Br}+\mathrm{O}_{3} \longrightarrow \mathrm{BrO}+\mathrm{O}_{2}
\end{aligned}
$$

$\mathrm{O}_{3}$ is removed in Reaction (R2) by $\mathrm{Br}$ to produce bromine monoxide (BrO). However, $\mathrm{BrO}$ is photolabile and can reproduce $\mathrm{O}_{3}$ and $\mathrm{Br}$ in a null cycle. Therefore, the rate at which $\mathrm{O}_{3}$ is destroyed is ultimately limited by the rate at which $\mathrm{BrO}$ reacts with another species to not reform $\mathrm{O}_{3}$, such as in Reactions (R3-R5).

$$
\begin{aligned}
\mathrm{BrO}+\mathrm{BrO} & \longrightarrow 2 \mathrm{Br}+\mathrm{O}_{2} \\
\mathrm{BrO}+\mathrm{ClO} & \longrightarrow \mathrm{BrCl}+\mathrm{O}_{2} \\
& \longrightarrow \mathrm{Br}+\mathrm{Cl}+\mathrm{O}_{2} \\
\mathrm{BrO}+\mathrm{HO}_{2} & \longrightarrow \mathrm{HOBr}+\mathrm{O}_{2}
\end{aligned}
$$

Note that $\mathrm{BrO}+\mathrm{ClO}$ (Reaction $\mathrm{R} 4$ ) can also produce $\mathrm{OClO}+\mathrm{Br}$; however, this pathway is not listed above since OClO primarily regenerates $\mathrm{O}_{3}$ in a null cycle via photolysis. Ozone destruction is propagated by the regeneration of reactive halogen species. In the gas phase, Reactions (R3) and (R4) are believed to dominate at high halogen-oxide concentrations, while R5 is believed to play a larger role at smaller BrO levels (Le Bras and Platt, 1995; Piot and von Glasow, 2008). Reactions (R3) and (R4) directly reproduce reactive $\mathrm{Br}$ atoms, while the $\mathrm{HOBr}$ formed by Reaction (R5) must first undergo photolysis (Simpson et al., 2007b, and references therein). Additionally, Reaction (R5) is involved in a series of heterogeneous, autocatalytic reactions referred to as the "bromine explosion", which are believed to supply net atmospheric reactive bromine (Fan and Jacob, 1992; Tang and McConnell, 1996; Vogt et al., 1996; Wennberg, 1999). The "bromine explosion" involves the production of
$\mathrm{HOBr}$ as above (R5), or through halogen reactions with oxidized nitrogen species (e.g., Aguzzi and Rossi, 2002; Hanson and Ravishankara, 1995). Uptake of this $\mathrm{HOBr}$ onto acidic, bromide-containing frozen surfaces produces $\mathrm{Br}_{2}$ (Adams et al., 2002; Huff and Abbatt, 2002), which can then undergo the $\mathrm{O}_{3}$-destroying reactions once photolyzed (R1). This series of reactions will exponentially increase $\mathrm{Br}_{2}$ levels until some required reagent runs out.

Hypothesized sources of reactive halogens include saline frozen surfaces found across the Arctic Ocean, such as the snowpack, blowing snow, and sea salt-derived aerosols (Abbatt et al., 2012; Fan and Jacob, 1992; Frieß et al., 2011; Jones et al., 2009; Simpson et al., 2005; Yang et al., 2008). Recent in situ experiments showed that saline, acidic surface snowpacks (above sea ice or tundra) can act as efficient sources of $\mathrm{Br}_{2}$, and that the "bromine explosion" can occur within the interstitial air of the snowpack, followed by release of reactive bromine into the boundary layer via wind pumping and diffusion (Pratt et al., 2013).

Despite our increasing understanding of the role of halogens in ODEs, basic ODE characteristics, such as their temporal and spatial scales, remain uncertain (Jacobi et al., 2010; Simpson et al., 2007b; Zeng et al., 2003). Current knowledge of the aforementioned $\mathrm{O}_{3}$ depletion chemical mechanisms $(\mathrm{CM})$ and the corresponding kinetics estimate the timescale for $\mathrm{O}_{3}$ destruction to be on the order of days (Hausmann and Platt, 1994; Jobson et al., 1994; Piot and von Glasow, 2008, 2009; Tuckermann et al., 1997). However, there are only a few reports of Arctic ODEs that are assumed/known to have been observed primarily as a result of local-scale CM (Boudries and Bottenheim, 2000; Jacobi et al., 2006). ODEs can also be observed primarily due to air mass transport mechanisms (TM) in which air masses depleted of $\mathrm{O}_{3}$ (via CM upwind) advect over the measurement site (Morin et al., 2005; Simpson et al., 2007b) and are detected as "ozone depletion events". Given that the Arctic Ocean surface is sunlit, stable against vertical mixing, and ice-covered during the spring (Lehrer et al., 2004), it has been hypothesized that $\mathrm{O}_{3}$ depleted surface air could be the norm in the Arctic boundary layer during this time, and that $\mathrm{O}_{3}$ is only observed at the surface due to turbulent vertical mixing in an otherwise stable boundary layer. This vertical mixing can temporarily transport free tropospheric $\mathrm{O}_{3}$ from aloft to the surface, raising the surface-level mole fractions to between 30 and $40 \mathrm{nmol} \mathrm{mol}^{-1}$ (Bottenheim et al., 2009; Hopper et al., 1998; Jacobi et al., 2010; Moore et al., 2014; Strong et al., 2002; Zeng et al., 2003). Regarding the spatial scales of individual $\mathrm{O}_{3}$-depleted air masses, Ridley et al. (2003) reported Arctic ODEs extending between 600 and $900 \mathrm{~km}$ in length from flights during the Tropospheric Ozone Production about the Spring Equinox experiment. Recently, Jones et al. (2013) reported the observation of multiple ODEs from a network of $10 \mathrm{O}_{3}$ monitors spread over the Droning Maud Land sector of Antarctica, some of which extended at least $1200 \mathrm{~km}$ in horizontal dimension. However, no such network of $\mathrm{O}_{3}$ monitors 
has yet been established in the Arctic to make analogous observations.

In a study of long-term Arctic coastal measurements, Tarasick and Bottenheim (2002) observed that ODEs most often occurred at temperatures of less than $253 \mathrm{~K}$, leading to the proposal that such low temperatures could be necessary for the initiation of ozone depletion. This hypothesis was strengthened by Adams et al. (2002), who reported that frozen $\mathrm{NaCl} / \mathrm{NaBr}$ surfaces efficiently uptake and react with $\mathrm{HOBr}$ to both form and release gas phase $\mathrm{Br}_{2}$ at temperatures below $253 \mathrm{~K}$. This observation has been hypothesized to occur due to the precipitation of $\mathrm{NaCl} \cdot 2 \mathrm{H}_{2} \mathrm{O}$ at temperatures less than $252 \mathrm{~K}$, which then requires a greater concentration of $\mathrm{Br}^{-}$to maintain the surface brine layer (Cho et al., 2002); when $\mathrm{Cl}^{-}$precipitates, the volume of the brine water must decrease to maintain the ionic concentration needed for the appropriate freezing point depression. Boundary-layer $\mathrm{BrO}$ enhancements have been correlated with low temperatures (Nghiem et al., 2012; Zeng et al., 2003), and apparently linear increases in maximum $\mathrm{BrO}$ concentrations have been observed with decreasing temperatures, below $258 \mathrm{~K}$ (Pöhler et al., 2010). Further, strong positive correlations between $\mathrm{O}_{3}$ concentration and potential temperature have been reported (Seabrook et al., 2011; Strong et al., 2002). However, Bottenheim et al. (2009) and Neuman et al. (2010) observed ODEs at temperatures as high as $267 \mathrm{~K}$, emphasizing uncertainty in the temperatures required for the observation of an $\mathrm{O}_{3}$ depleted air mass.

ODEs have often been associated with a calm, stable boundary layer. Events observed under high wind speeds (faster than $10 \mathrm{~m} \mathrm{~s}^{-1}$ ) are generally attributed to TM (Simpson et al., 2007b). Yang et al. (2008) hypothesized that saline snow atop sea ice could disperse during periods of high wind and become a source of both sea-salt aerosol and bromine, consequently initiating ODEs. Indeed, there have been coastal-based studies in which increased $\mathrm{BrO}$ and aerosol were observed during periods of elevated wind speeds $\left(>5 \mathrm{~m} \mathrm{~s}^{-1}\right)$, and $\mathrm{O}_{3}$ depletion sometimes, but not always, followed (Frieß et al., 2011; Jones et al., 2009). Alternatively, higher wind speeds could also lead to better ventilation of the snowpack in which $\mathrm{Br}_{2}$ is produced (Albert et al., 2002; Foster et al., 2001; Michalowski et al., 2000; Pratt et al., 2013; Toyota et al., 2011). Michalowski et al. (2000) discussed that the rate at which $\mathrm{HOBr}$ reacts with $\mathrm{Br}^{-}$during $\mathrm{Br}_{2}$ production in the "bromine explosion" was dependent on the timescale for turbulent diffusive transport of $\mathrm{HOBr}$ to the snowpack surface, which would be wind-speed dependent. However, due to few coincident observations of wind speeds, aerosol, $\mathrm{O}_{3}$, and $\mathrm{BrO}$, the dependence of ODEs on wind speed remains unclear.

Arctic air masses depleted in $\mathrm{O}_{3}$ typically spend a significant amount of time over the Arctic Ocean before arriving at coastal measurement sites, suggesting that the ice-covered ocean is the most probable site of ODE initiation (Bottenheim and Chan, 2006; Gilman et al., 2010; Jacobi et al.,

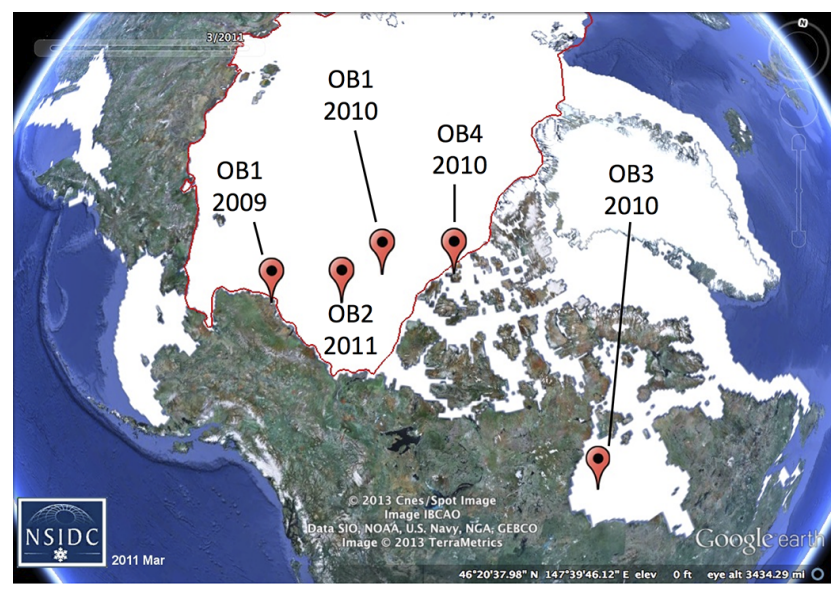

Figure 1. Map of locations at which various O-Buoys (abbreviated OB) were deployed between 2009 and 2011. For the coordinates, see Table 1. Sea ice extent image is for the month of March 2011. Map courtesy of Google Earth, and sea ice image courtesy of the National Snow and Ice Data Center.

2006; Simpson et al., 2007a). In situ chemical and meteorological data from the Arctic Ocean are, however, sparse. Most long-term Arctic tropospheric $\mathrm{O}_{3}$ measurements have been made at coastal sites, and thus most observed ODEs have been attributed to TM. Attempts to study ODEs over the Arctic Ocean have been conducted on ice floes (e.g., Hopper et al., 1994; Hopper et al., 1998), aircraft (e.g., Jaeschke et al., 1999; Leaitch et al., 1994; Neuman et al., 2010; Ridley et al., 2003; Seabrook et al., 2013; Sheridan et al., 1993), and ships (e.g., Bottenheim et al., 2009; Gilman et al., 2010; Jacobi et al., 2006; Nghiem et al., 2012; Pöhler et al., 2010; Seabrook et al., 2011). However, few of these studies have produced the long-term data required for in-depth studies of the temporal and spatial scales of ODEs.

Recently, a series of ice-tethered buoys were deployed as part of the Arctic Observing Network program to observe ODEs over the Arctic Ocean (Knepp et al., 2010). The buoys have been installed in sea ice for automated, continuous, several-month surface measurements of $\mathrm{O}_{3}, \mathrm{BrO}$ (Carlson et al., 2010), carbon dioxide, and local meteorological conditions. The data generated by the O-Buoys represent the first long-term measurements of these chemical species directly over the surface of the ice-covered Arctic Ocean. Using this unique data set, we estimate the timescales of $\mathrm{O}_{3}$ depletion, examine the state of our understanding of the chemistry involved, and estimate the spatial extents and meteorological conditions supporting $\mathrm{O}_{3}$-depleted air masses. 

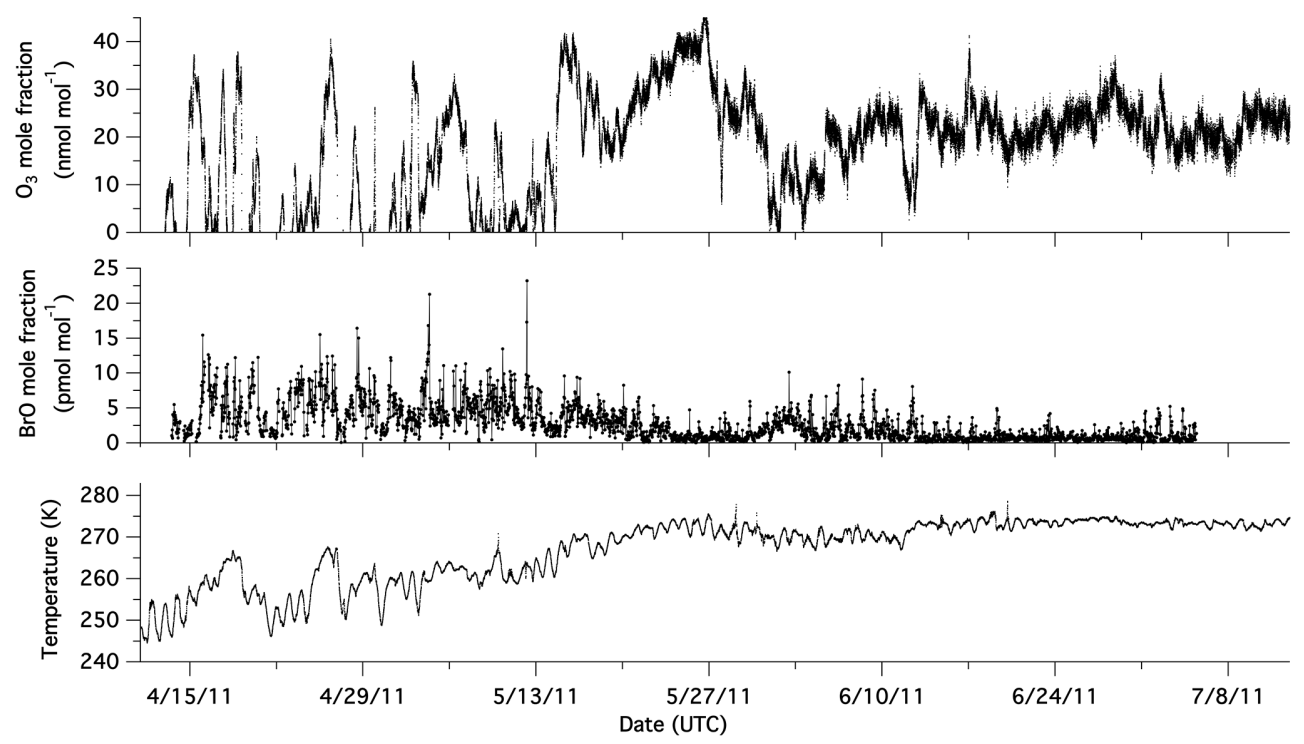

Figure 2. Example time series of $\mathrm{O}_{3}, \mathrm{BrO}$, and temperature from $\mathrm{O}-\mathrm{Buoy} 2$ during its deployment in the Beaufort Sea.

\section{Experimental}

\subsection{Instrumentation}

Surface $\mathrm{O}_{3}$ and meteorology measurements discussed herein were collected during five separate deployments of O-Buoys (Table 1). Buoy deployment locations are shown in Fig. 1. Details of the O-Buoy design and operation are discussed extensively by Knepp et al. (2010), but a brief description of the meteorological, $\mathrm{O}_{3}$, and $\mathrm{BrO}$ instruments are given herein. At the time of data analysis, $\mathrm{BrO}$ data were available from both O-Buoy1 (Barrow, Alaska, 2009 deployment) and O-Buoy2 (Beaufort Sea, 2010-2011 deployment) to compare with $\mathrm{O}_{3}$ depletion timescales. The O-Buoy2 time series, including $\mathrm{O}_{3}, \mathrm{BrO}$, and temperature, is presented in Fig. 2. During winter months, O-Buoys are set to operate on an abbreviated sampling schedule to conserve power, typically sampling for a total of $4 \mathrm{~h}$ once every $1-3$ days. The O-Buoys were switched to daily $24 \mathrm{~h}$ sampling close to the time of polar sunrise, typically near the end of February or early March. The MAX-DOAS (multiaxis differential optical absorption spectroscopy) instrument was an exception to this sampling schedule as it was kept unpowered during the winter months, and turned on during the springtime switch to $24 \mathrm{~h}$ sampling. Though the O-Buoys are also active during fall, winter, and late summer months, we focus mostly on springtime and early summer data herein (dates presented in Table 1).

Temperature was measured using a Vaisala model HMP45C temperature and relative humidity probe. Wind speed was measured using a RM Young Model 05103 anemometer. The range of wind speeds observed across the four O-Buoys deployed was $0-15 \mathrm{~m} \mathrm{~s}^{-1}$. It was observed during the 2009 Barrow, Alaska, O-Buoy1 deployment, how- ever, that the anemometer was susceptible to icing, which would impede its ability to spin freely and provide accurate measurements. This effect was most prominent during the same deployment, in which wind speed fell from a mean of about 2 to $0 \mathrm{~m} \mathrm{~s}^{-1}$ for a period of 4 days. To mitigate the impact of this effect on the interpretation of the results, wind data were not utilized in our analysis when wind speed was measured as $0 \mathrm{~m} \mathrm{~s}^{-1}$. While there is reason to believe that wind speeds are indeed low during these periods, the actual wind speed is unknown. Thus, if the average wind speed calculated during an ODE contained $>50 \%$ of such values, the wind data for that event were not included in the data analysis. We also acknowledge that an icing effect could create a measurement bias toward lower values. However, as discussed in the text (Sect. 3.3), on average this appears to be a minor issue in terms of our use of the anemometer data (e.g., to calculate ODE spatial scales) as we find effectively equivalent results using our anemometer wind speeds and those estimated using the HYSPLIT backwards trajectory model (Sect. 2.3).

Ozone was measured using custom-built 2B Technologies model 205 dual-beam $\mathrm{O}_{3}$ monitors. Customizations include one backup pump, one backup $\mathrm{O}_{3}$ scrubber, a lamp heater, and modified firmware to control the instrument remotely. The instrument inlet was located on the mast of the buoy $2 \mathrm{~m}$ above the sea ice and contained a $90 \mathrm{~mm}$ quartz fiber filter (Pall Life Sciences) to prevent intake of large particles. The instrument itself is located inside the hull of the buoy beneath the sea ice such that it operates under a near constant temperature $\left(\sim-1.5^{\circ} \mathrm{C}\right)$. The $\mathrm{O}_{3}$ instrument did not display a temperature dependence during laboratory, pre-deployment $\mathrm{O}_{3}$ calibrations as long as the cell temperature of the instrument was stable; cell temperature stabilization generally occurred 
Table 1. O-Buoy deployment locations and time periods of continuous measurements focused on herein.

\begin{tabular}{llllll}
\hline $\begin{array}{l}\text { O-Buoy } \\
\text { number }\end{array}$ & Latitude & Longitude & General area & $\begin{array}{l}\text { Dates of continuous } \\
\text { measurements }\end{array}$ & $\begin{array}{l}\text { Number of ODEs } \\
\text { observed }\end{array}$ \\
\hline 1 & $71^{\circ} \mathrm{N}$ & $156^{\circ} \mathrm{W}$ & Barrow, Alaska & 2 Mar 2009-19 May 2009 & 13 \\
1 & $77^{\circ} \mathrm{N}$ & $135^{\circ} \mathrm{W}$ & Beaufort Sea & 22 Mar 2010-14 Jul 2010 & 13 \\
2 & $74^{\circ} \mathrm{N}$ & $142^{\circ} \mathrm{W}$ & Beaufort Sea & 11 Apr 2011-22 Jul 2011 & 6 \\
3 & $60^{\circ} \mathrm{N}$ & $90^{\circ} \mathrm{W}$ & Hudson Bay & 22 Feb 2010-27 Mar 2010 & 3 \\
4 & $78^{\circ} \mathrm{N}$ & $112^{\circ} \mathrm{W}$ & Borden Island, Nunavut, Canada & 04 Apr 2010-30 Apr 2010 & 3 \\
\hline
\end{tabular}

Table 2. Cross sections used in spectral analysis. Each cross section is convolved using an instrument function determined by the $334 \mathrm{~nm}$ $\mathrm{Hg}$ peak.

\begin{tabular}{ll}
\hline Species & Cross section reference \\
\hline $\mathrm{BrO}(228 \mathrm{~K})$ & Wilmouth et al. (1999) \\
$\mathrm{O}_{3}(243 \mathrm{~K})$ & Malicet et al. (1995) \\
$\mathrm{NO}_{2}(220 \mathrm{~K})$ & Vandaele et al. (1998) \\
$\mathrm{O}_{4}$ & Hermans et al. (2001) \\
$\mathrm{Ring}$ & Determined from zenith spectra \\
& using Chance and Spurr (1997) \\
\hline
\end{tabular}

after 20-30 min, and the first $30 \mathrm{~min}$ of $\mathrm{O}_{3}$ data during these warm-up periods were excluded from data analysis. The instrument has a manufacturer specified limit of detection of $1 \mathrm{nmol} \mathrm{mol}^{-1}$, and individual measurement uncertainty was calculated to range from 2.1 to $3.5 \mathrm{nmol} \mathrm{mol}^{-1}$. Ozone monitor averaging times differed between buoy deployments: OBuoy1 used $10 \mathrm{~s}$ averages, O-Buoy 3 used $2 \mathrm{~s}$ averages, and both $\mathrm{O}-\mathrm{Buoy} 2$ and $\mathrm{O}-\mathrm{Buoy} 4$ used $1 \mathrm{~min}$ averages. For analysis, all data were smoothed to 5 min moving averages.

$\mathrm{BrO}$ was detected using a MAX- DOAS instrument. The scan head telescope, located at the top of the buoy mast, collects scattered radiation and sends it through a fiber optic cable to the computer/spectrometer module, which consists of a single board computer (Technologic Systems TS7260), a stepper motor driver (Stepperboard BC2D15), interface electronics, and a miniature spectrometer (Ocean Optics HR2000, 318-455 nm). The scan elevation angle is controlled by the O-Buoy's supervisory computer and observes light at angles of 90 (zenith), 20, 10, 5, 2, and $1^{\circ}$ over a period of $30 \mathrm{~min}$ (Carlson et al., 2010). The zenith spectrum from a 30 min data measurement period was used as the reference spectrum for the lower elevation angle spectra, which minimizes the differential absorption by stratospheric species. To obtain differential slant column densities (dSCD), the QDOAS software was used (Fayt et al., 2011) to fit both the logarithm of the ratio of each low elevation spectra and zenith spectra in the wavelength region 346-364 nm (convolved absorber cross sections detailed in Table 2), as well as a thirdorder polynomial to account for broadband features and a spectral offset to account for stray light. Fit residuals for both
O-Buoy1 and O-Buoy2 were less than $1 \times 10^{-3}$ resulting in $\mathrm{BrO} \mathrm{dSCD}$ errors of less than $4 \times 10^{13}$ molecules $\mathrm{cm}^{-2}$ and $\mathrm{O}_{4} \mathrm{dSCD}$ errors of less than $1 \times 10^{42}$ molecules $^{2} \mathrm{~cm}^{-5}$. Retrieval of $\mathrm{BrO}$ mole fractions from dSCD data is a twostep inverse problem. First, the aerosol profile is determined from $\mathrm{O}_{4} \mathrm{dSCDs}$ using both the SCIATRAN radiative transfer model as a forward model, and the estimation techniques detailed in Frieß et al. (2006). Then, a vertical profile of BrO mole fractions from the ground to $2 \mathrm{~km}$ ( $100 \mathrm{~m}$ intervals) was obtained using both the radiative transfer model McArtim (Deutschmann et al., 2011) as a forward model, and similar optimal estimation techniques detailed in Frieß et al. (2011). Because we are only considering surface $\mathrm{O}_{3}$ measurements, only the average $\mathrm{BrO}$ mole fractions in the lowest $100 \mathrm{~m}$ were used in subsequent portions of this study.

The $\mathrm{BrO}$ detection limit is a function of the geometry of the observation and the state of the atmosphere at the time of the measurement. We estimated a range for the detection limit $(2 \sigma)$ from $3.7 \times 10^{12}$ (clear sky) to $1.5 \times 10^{13} \mathrm{~mol} \mathrm{~cm}^{-2}$ (impaired visibility) for the total integrated column $\mathrm{BrO}$ through $2 \mathrm{~km}\left(\mathrm{VCD}_{2 \mathrm{~km}}\right)$ by looking at the distribution of $\mathrm{VCD}_{2 \mathrm{~km}}$ values over a month in late summer where no $\mathrm{BrO}$ was observed. To evaluate the error associated with the retrieved surface mole fractions, it is necessary to consider both dSCD measurement error and smoothing error (Rodgers, 2000). Smoothing error calculations quantify the error resulting from the inability of the instrument to observe fine structure in the vertical profile. The smoothing error was estimated through considering the mean of an ensemble of profiles retrieved in late summer $(\bar{x})$ when the dSCD measurements indicated no measurable BrO. This allowed us to assume the actual profile $\left(x_{\mathrm{a}}\right)$ is given by $0 \mathrm{pmol} \mathrm{mol}^{-1}$ (pptv, parts per trillion by volume) $\mathrm{BrO}$ through $2 \mathrm{~km}$. The average surface mole fraction smoothing errors $\left(\epsilon_{\mathrm{s}}\right)$ for the entire OBuoy 2 campaign were estimated using Eq. 1, where $A$ represents the averaging kernel matrix and $I$ is the identity matrix (Rodgers, 2000).

$\epsilon_{\mathrm{s}}=(A-I)\left(\bar{x}-x_{\mathrm{a}}\right)$

Individual surface mole fraction errors due to smoothing error averaged $0.3 \mathrm{pmol} \mathrm{mol}^{-1}$ for the O-Buoy 2 campaign. Including individual mole fraction errors due to propagated dSCD measurement error, total surface mole fraction errors 

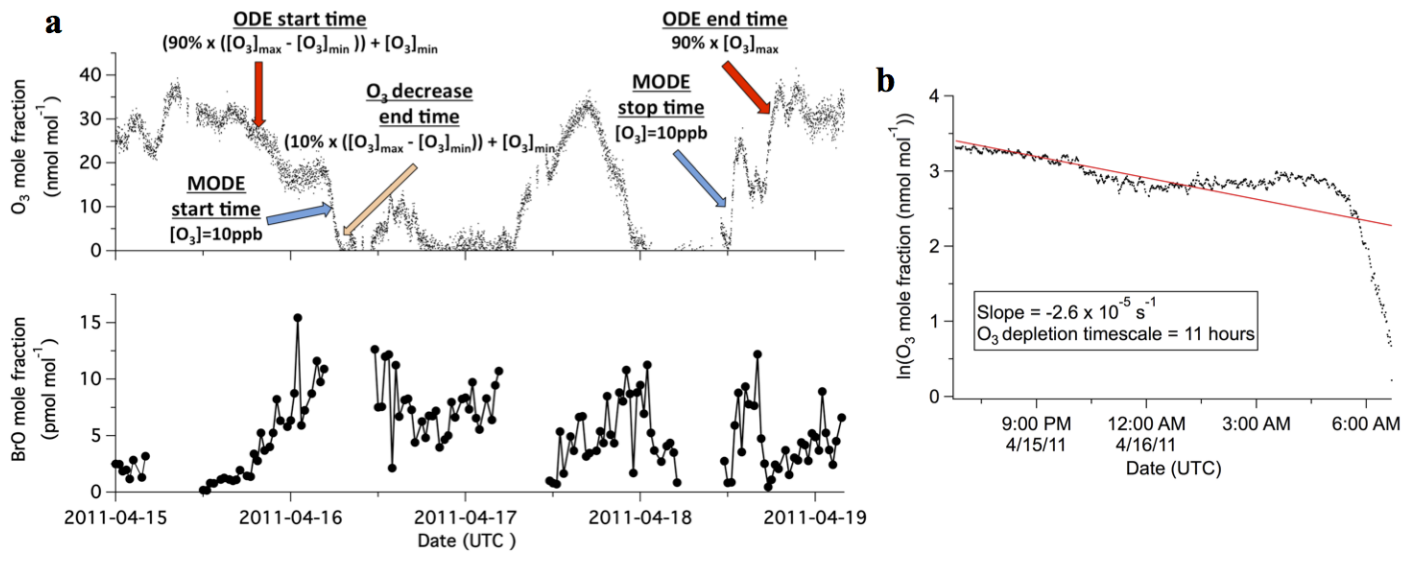

Figure 3. (a) Example ODE from O-Buoy2 deployment in the Beaufort Sea with ODE definitions illustrated. The brief resurgence of $\mathrm{O}_{3}$ on 17 April does not rise above $25 \mathrm{nmol} \mathrm{mol}^{-1}$ for longer than $12 \mathrm{~h}$ and is thus not considered as separating two ODEs. Error bars are not displayed to more clearly show the time series. As discussed in Sect. 2.1, individual measurement errors for $\mathrm{O}_{3}$ ranged from 2.1 to $3.5 \mathrm{nmol} \mathrm{mol}^{-1}$, and BrO measurement errors ranged from 0.7 to $6.9 \mathrm{pmol} \mathrm{mol}^{-1}$ (median and average error $\sim 3 \mathrm{pmol} \mathrm{mol}^{-1}$ ). (b) Example of $\mathrm{O}_{3}$ depletion timescale calculation based on the depletion range (ODE start time $-\mathrm{O}_{3}$ decrease end time) from (a). The natural logarithm of the $\mathrm{O}_{3}$ values is plotted against time, and the inverse slope of this plot represents the $\mathrm{O}_{3}$ depletion timescale.

range from 0.7 to $6.9 \mathrm{pmol} \mathrm{mol}^{-1}$, with average and median errors corresponding to $\sim 3.0$ and $3.3 \mathrm{pmol} \mathrm{mol}^{-1}$ respectively. Due to the timing of the O-Buoy1 deployment at Barrow, we were unable to estimate smoothing error in the manner described above. Therefore, only errors due to propagated dSCD measurement error were considered. For O-Buoy 1, total surface mole fraction errors range from 0.7 to $4.5 \mathrm{pmol} \mathrm{mol}^{-1}$, with average and median errors corresponding to $\sim 2.5$ and $2.6 \mathrm{pmol} \mathrm{mol}^{-1}$ respectively.

\subsection{ODE definition}

Ozone depletion events and "major" ozone depletion events (MODEs) are defined when $\mathrm{O}_{3}$ drops below 15 and $10 \mathrm{nmol} \mathrm{mol}^{-1}$, respectively, for longer than $1 \mathrm{~h}$. The MODE acronym was also utilized by Ridley et al. (2003), and we emphasize that our definition differs from theirs (a larger discussion of ODE definitions in the scientific literature is presented in the Supplement). The ODE start time is the time at which $\mathrm{O}_{3}$ falls from background $\mathrm{CO}_{3}$ mole fraction $>25 \mathrm{nmol} \mathrm{mol}^{-1}$ for at least $12 \mathrm{~h}$ ) to below the $90 \%$ value of the mole fraction range during depletion. The ODE stop time is defined by the time when $\mathrm{O}_{3}$ recovers to $90 \%$ of the local maximum $\mathrm{O}_{3}$ mole fraction after rising above $25 \mathrm{nmol} \mathrm{mol}^{-1}$ (if background concentrations will ultimately be reestablished). For MODEs, the start time is the time at which $\mathrm{O}_{3}$ falls below $10 \mathrm{nmol} \mathrm{mol}^{-1}$, and the stop time is the time when $\mathrm{O}_{3}$ rises above $10 \mathrm{nmol} \mathrm{mol}^{-1}$ (if the $\mathrm{O}_{3}$ mole fraction will stay above $10 \mathrm{nmol} \mathrm{mol}^{-1}$ for at least $12 \mathrm{~h}$ ). Finally, for the calculation of the $\mathrm{O}_{3}$ depletion timescale, an $\mathrm{O}_{3}$ decrease stop time was defined as the time at which $\mathrm{O}_{3}$ first reached $10 \%$ of the $\mathrm{O}_{3}$ mole fraction range during $\mathrm{O}_{3}$ depletion. These definitions are illustrated by Fig. 3a, and are further discussed in the Supplement. It should be noted that the increase in $\mathrm{O}_{3}$ mole fraction on 17 April 2011 seen in Fig. 3 does not recover above $25 \mathrm{nmol} \mathrm{mol}^{-1}$ for longer than $12 \mathrm{~h}$, and its subsequent decrease does not represent a new ODE.

\subsection{Air mass trajectory analysis}

The NOAA HYSPLIT (Hybrid Single Particle Lagrangian Integrated Trajectory) air mass trajectory model (Draxler and Hess, 1997, 1998; Draxler, 1999) was utilized to examine backward trajectories during $\mathrm{O}_{3}$-depleted conditions, as defined in Sect. 2.2. Backward air mass trajectories were calculated starting from a height of $10 \mathrm{~m}$ above ground level using the ODE stop time as the start time of the model (note that three events, one from each O-Buoy 2,3 , and 4 , did not have well-defined ODE stop times, and thus could not undergo this analysis). Isobaric trajectories were chosen because the stable surface air in which the ODEs occur is typically well isolated from the air aloft (Oltmans et al., 2012; Seabrook et al., 2013); as long as $\mathrm{O}_{3}$ is in ODE conditions, the air is likely to be surface layer air. The trajectory run lengths were defined by the ODE durations (ODE stop time - ODE start time; see Fig. S1 in the Supplement for the distribution of ODE time lengths), such that the final point of the backward trajectories corresponded to the defined ODE start times. ODE spatial scales were defined as the maximum distance between any two points of the backward air mass trajectory, as this would represent an upper limit to an event's 
spatial size (illustrated visually in Fig. 4). This analysis was performed for both the broader ODE definition and MODEs. Of the ODE air masses modeled isobarically, all but one remained near the surface (below $200 \mathrm{~m}$ above ground level) throughout the course of the trajectory. The outlying ODE air mass, occurring during O-Buoy1 2009 at Barrow, AK, rose above $800 \mathrm{~m}$ and likely did not represent surface layer air; this event was therefore excluded from HYSPLIT analyses. For comparison, we also estimated the ODE spatial scales by the same method using isentropic back trajectories (starting height of $10 \mathrm{~m}$ above ground level); by determining the distance between the start and end points for each isobaric trajectory; and by using Eq. (2):

$D_{\mathrm{ODE}}=v_{\text {wind }} \times t_{\mathrm{ODE}}$,

where $D_{\mathrm{ODE}}$ is the ODE diameter, $v_{\text {wind }}$ is the average local wind speed from the anemometer, and $t_{\mathrm{ODE}}$ is the duration of the ODE.

The HYSPLIT model was also used to estimate some meteorological parameters at each position along the isobaric backward trajectories. For this analysis, the average and minimum air temperatures along each trajectory were compared with the temperatures recorded by the O-Buoy during each ODE. The path lengths and time lengths of individual trajectories were used to estimate the average wind speeds of the air masses, which were compared with the wind speeds obtained from the O-Buoy anemometer. Wind rose plots were created based on the quadrant in which the air mass trajectory spent the most time during a given ODE (north $\left(315-45^{\circ}\right)$, south $\left(135-225^{\circ}\right)$, east $\left(45-135^{\circ}\right)$, and west $\left(225-315^{\circ}\right)$ ). Only four quadrants were used in the wind rose plots because there is a large level of uncertainty associated with using a back trajectory model for this purpose (Kahl, 1993). The angles used were obtained by calculating the bearing between the O-Buoy and each point along each back trajectory for each ODE.

\subsection{Monte Carlo experiment}

A Monte Carlo experiment was performed to determine whether it was statistically possible that the observed ODEs resulted primarily from TM, given the estimated size distribution. In the limit of an ODE as large as the Arctic Ocean, the ODE would be observed at the O-Buoy primarily due to local CM. Thus, for some ODE size limit, it is not feasible for all ODE observations to result from TM. For this simulation experiment, we estimated the probability that assumed circular depletion regions overlap with a point of interest (an O-Buoy) when randomly placed about a defined area represented by the ice-covered Arctic Ocean. The diameters of the circles were defined by the ODE size distribution estimated from Beaufort Sea (O-Buoy1 and O-Buoy2) observations (Sect. 2.3); these particular ODEs were chosen for this exercise because of the similar locations and drift trajectories of the buoys, providing the needed statistics for the analy-

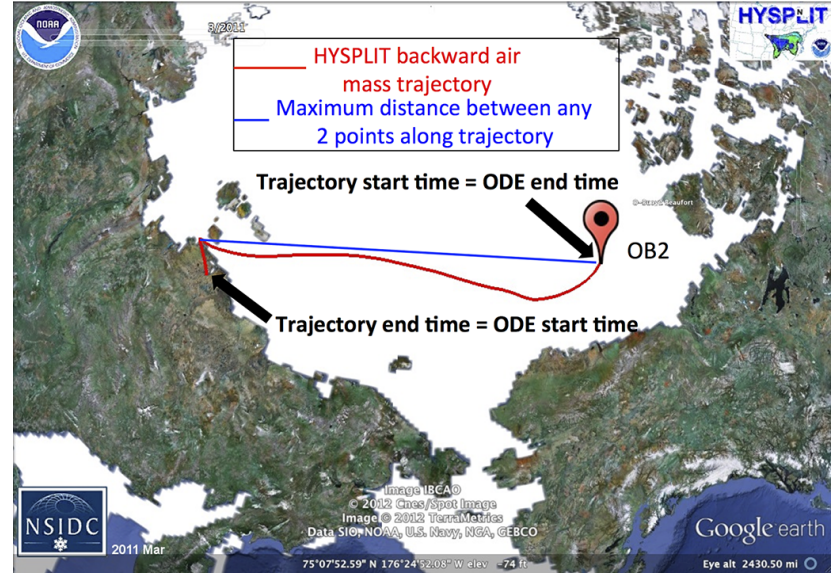

Figure 4. Example HYSPLIT backward air mass trajectory. The HYSPLIT model was run backward starting from the ODE end time until the ODE start time. ODE spatial dimensions were determined by calculating the maximum great circle distance between any two points along the trajectory.

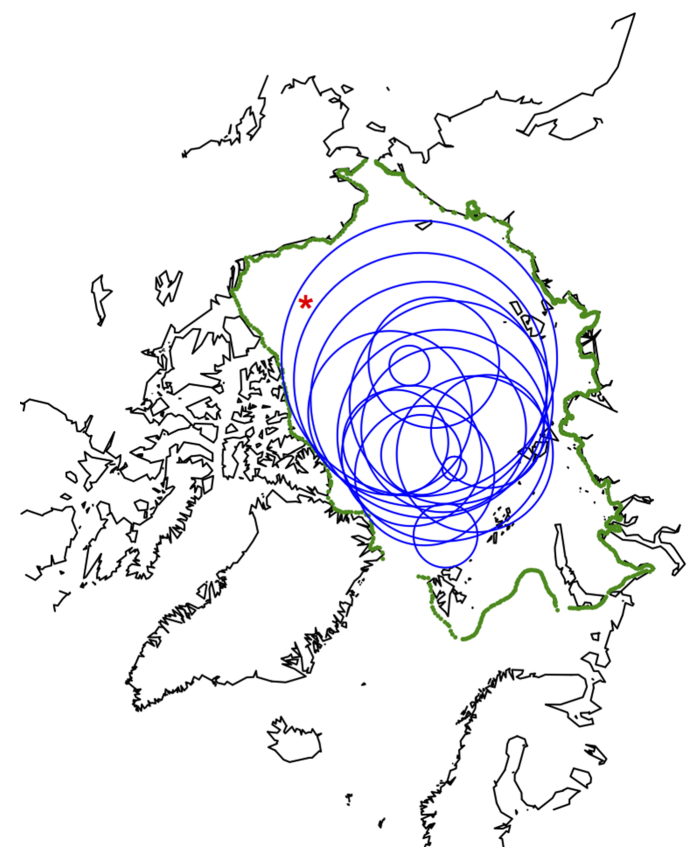

Figure 5. Visualization of one iteration out of 2000 of the Monte Carlo experiments. The area of interest within the Arctic is defined by the green outline. Blue circles represent ODE air masses. The red star represents the average location of the O-Buoy between $\mathrm{O}$ Buoys1 and 2. Seventeen different-sized air masses were randomly placed simultaneously within the area of interest.

sis. Nineteen ODEs were observed between the two deployments (in 2010 and 2011), with ODE sizes ranging from 210 to $3532 \mathrm{~km}$ (Supplemental Information Fig. S2). The circles, with sizes taken from the observed size distribution, were simultaneously and randomly placed in an area defined by the 
average sea ice extent of the Arctic Ocean between March 2010 and 2011 (Fig. 5), as reported by the National Snow \& Ice Data Center (http://www.nsidc.org/). We note, however, two O-Buoy2 events were excluded from this analysis. The first was removed due to an undefined ODE spatial scale (discussed in Sect. 2.3). The other ODE size excluded (diameter of $3532 \mathrm{~km}$ ) was estimated to be larger than the defined area. Thus, a total of 17 circles were used in these simulations. The number of circles that overlapped with the location of the buoy (assumed to be $74.75^{\circ} \mathrm{N}, 142^{\circ} \mathrm{W}$, an approximate location of both O-Buoy 1 and 2) was determined for multiple iterations of the experiments. Figure 5 represents one iteration of the experiment, which was repeated 2000 times in order to obtain a statistical distribution of the number of overlaps. Additionally, a sequence of similar Monte Carlo experiments was repeated for individual ODE sizes 1000 times to obtain the probability that each circle size overlaps with the location of the buoy. This simulation experiment was conducted to examine the relationship between ODE size and the probability that the ODE would only be observed due to TM.

\section{Results and discussion}

\subsection{Ozone depletion timescale}

For O-Buoys 1-4, a total of 38 ODEs were observed between the months of February and June (see Table 1 for breakdown of each O-Buoy). On the assumption that $\mathrm{O}_{3}$ decrease is an exponential decay process, and to express the observed depletion timescales in an objective manner, the apparent $\mathrm{O}_{3}$ depletion timescale $\left(\tau_{\mathrm{O}_{3}}\right)$ at the beginning of an ODE was estimated as the reciprocal of the slope of $\ln \left[\mathrm{O}_{3}\right]$ versus time (during the period ODE start time $-\mathrm{O}_{3}$ decrease stop time, as discussed in Sect. 2.2; Fig. 3b). This timescale is observed due to a combination of both $\mathrm{CM}$ and TM, though the extent to which each factor affects $\tau_{\mathrm{O}_{3}}$ is unknown. Because we are analyzing the slopes, this analysis is mostly insensitive to the ODE start/depletion stop times as long as the depletion range of the plot constitutes the majority of the defined time frame. As seen in Fig. $6 \mathrm{a}, \tau_{\mathrm{O}_{3}}$ ranged from $30 \mathrm{~min}$ to longer than $50 \mathrm{~h}$ (maximum of 14 days), with the majority (76\%) shorter than $24 \mathrm{~h}$ (median $\tau_{\mathrm{O}_{3}}$ of $11 \mathrm{~h}$ ). These timescales correspond to $\mathrm{O}_{3}$ decrease rates $\left(-\frac{d\left[\mathrm{O}_{3}\right]}{d t}\right)$ that range between 0.02 and $30 \mathrm{nmol} \mathrm{mol}^{-1} \mathrm{~h}^{-1}$ (average and standard deviation: $3.5 \pm 5.4 \mathrm{nmol} \mathrm{mol}^{-1} \mathrm{~h}^{-1}$ ). By comparison, Tuckermann et al. (1997) reported $\mathrm{O}_{3}$ decrease rates ranging from 0.24 to $7 \mathrm{nmol} \mathrm{mol}^{-1} \mathrm{~h}^{-1}$ from their measurements in $\mathrm{Ny}$ Alesund, Spitsbergen. Removing coastal site data (O-Buoy1 2009, deployed in Barrow, AK) from the histogram did not significantly alter the $\tau_{\mathrm{O}_{3}}$ distribution. For the six ODEs with $\tau_{\mathrm{O}_{3}}$ equal to $50 \mathrm{~h}$ or longer, two cases occurred in June after changes in $\mathrm{O}_{3}$ levels had become much more gradual, relative to the sporadic and episodic nature of the preceding months (February-May). Apart from these two events, which occurred at higher temperatures, there was no clear difference in the local average wind speeds or temperatures that was unique to the remaining four of these six events. However, a likely cause for these extended events is poor vertical mixing in the absence of frontal passages. Recent work by Moore et al. (2014) provides evidence of coastal $\mathrm{O}_{3}$ recovery to background levels when air passes over open leads. This recovery is hypothesized to occur due to increased convective mixing and downward transport of ozone from aloft. Thus, a longer depletion timescale may also imply a largescale ice-covered surface.

If the observed ODEs were indeed dominated by the $\mathrm{CM}$ at the location of the O-Buoys (i.e., TM is minimized in the apparent $\tau_{\mathrm{O}_{3}}$ ), it is surprising that the majority of cases featured such short apparent timescales of $\mathrm{O}_{3}$ depletion $\left(\tau_{\mathrm{O}_{3}}<12 \mathrm{~h}\right)$. As discussed in Sect. 1, most previous model estimates of $\mathrm{O}_{3}$ depletion timescales due to chemistry are on the order of days (Hausmann and Platt, 1994; Jobson et al., 1994; Piot and von Glasow, 2008, 2009; Tuckermann et al., 1997). Generally, fast $\tau_{\mathrm{O}_{3}}$ observed at coastal sites have been attributed to TM. In these cases, $\mathrm{O}_{3}$ has been hypothesized to be chemically destroyed upwind (i.e., over the Arctic Ocean), and the apparent $\tau_{\mathrm{O}_{3}}$ is a function of both the rate at which the $\mathrm{O}_{3}$ depleted air mass travels across the measurement site and the horizontal concentration gradient at the edges of those air masses. For example, Morin et al. (2005) observed $\mathrm{O}_{3}$ levels to fall from mole fractions of $\sim 30 \mathrm{nmol} \mathrm{mol}^{-1}$ to less than $5 \mathrm{nmol} \mathrm{mol}^{-1}$ in around $3 \mathrm{~min}$ from over the Arctic Ocean, $6 \mathrm{~km}$ off the coast of Alert, Canada. However, fast $\mathrm{O}_{3}$ depletion attributed to local chemistry has been previously reported: using measurements from aboard the icebreaker RV Polarstern in the Arctic Ocean, Jacobi et al. (2006) observed a decrease in $\mathrm{O}_{3}$ from 40 to $<1 \mathrm{nmol} \mathrm{mol}^{-1}$ in less than $7 \mathrm{~h}$.

To interpret the results from the O-Buoys, we first explore the extent to which known chemical mechanisms could account for the observed $\tau_{\mathrm{O}_{3}}$ values (i.e., the $\mathrm{CM}$ dominates while the TM is minimal). Rates of $\mathrm{O}_{3}$ loss during ODEs have been previously thought to be limited by Reactions (R3, R4) at high BrO levels, estimated by Eq. (3) below (Le Bras and Platt, 1995; Platt and Janssen, 1995).

$$
\left(-\frac{d\left[\mathrm{O}_{3}\right]}{d t}\right)=2 k_{\mathrm{BrO}+\mathrm{BrO}}[\mathrm{BrO}]^{2}+2 k_{\mathrm{BrO}+\mathrm{ClO}}[\mathrm{BrO}][\mathrm{ClO}]
$$

Recently, Liao et al. (2012) and Liao et al. (2014) report that (R3) and (R4) only account for around $40 \%$ of the total $\mathrm{O}_{3}$ depletion chemistry during the 2009 OASIS field campaign. Thompson et al. (2014), using a 0-D model constrained by chemical data collected during the same campaign, found that $\mathrm{Br}$-atom destruction of $\mathrm{O}_{3}$ has a low homogeneous gas phase radical propagation chain length (close to 1). Because of this small chain length, the dominant source of $\mathrm{Br}$ atoms that destroy $\mathrm{O}_{3}$ appears to be the photolysis of $\mathrm{Br}_{2}$ and $\mathrm{BrCl}$ emitted from the surface or aerosols (Thompson et al., 2014), and thus most of the $\mathrm{BrO}$ that is produced terminates via reaction with $\mathrm{HO}_{2}$ (Reaction R5) (or $\mathrm{NO}_{2}$ for more polluted 
areas, such as Barrow, AK). Indeed, estimating the rate using Eq. (3) assumes that all $\mathrm{Br}$ atoms are produced from Reactions (R3) and (R4), which is inconsistent with the observed, often large concentrations of $\mathrm{Br}_{2}$ (Liao et al., 2012). The $\mathrm{BrO}$ termination pathways would result in more heterogeneous recycling of $\mathrm{Br}$ atoms. They then compared $\frac{d\left[\mathrm{O}_{3}\right]}{d t}$ as calculated by both Eq. (3) and by the net chemical $\mathrm{O}_{3}$-destruction rate (Eq. 4).

$$
\left(-\frac{d\left[\mathrm{O}_{3}\right]}{d t}\right)=
$$

$$
\begin{aligned}
& k[\mathrm{Br}]\left[\mathrm{O}_{3}\right]+k[\mathrm{Cl}]\left[\mathrm{O}_{3}\right]+k\left[\mathrm{O}\left({ }^{1} \mathrm{D}\right)\right]\left[\mathrm{H}_{2} \mathrm{O}\right]+ \\
& k[\mathrm{OH}]\left[\mathrm{O}_{3}\right]+k\left[\mathrm{HO}_{2}\right]\left[\mathrm{O}_{3}\right]-k[\mathrm{BrO}][\mathrm{NO}]- \\
& J[\mathrm{BrO}]-k[\mathrm{ClO}][\mathrm{NO}]-J[\mathrm{ClO}]
\end{aligned}
$$

In calculating $\frac{d\left[\mathrm{O}_{3}\right]}{d t}$, a regression between the rates showed that using only Eq. (3) underestimates the net $\frac{d\left[\mathrm{O}_{3}\right]}{d t}$ (from Eq. 4) by a factor of 4.1 on average by neglecting other chemical pathways (Thompson et al., 2014). Therefore, we estimate the $\mathrm{BrO}$ mole fractions required to cause the observed $\tau_{\mathrm{O}_{3}}$ according to Eqs. (5) and (6) below. These equations include the factor of 4.1 that accounts for the production of bromine atoms via $\mathrm{Br}_{2}$ and $\mathrm{BrCl}$ photolysis, two molecular halogens derived from heterogeneous recycling of species such as $\mathrm{HOBr}$ and $\mathrm{BrONO}_{2}$ on halidecontaining aerosols or the saline snowpack (Abbatt et al., 2012; Simpson et al., 2007b). A constant ClO concentration of $1.7 \times 10^{8}$ molecules $\mathrm{cm}^{-3}\left(6 \mathrm{pmol} \mathrm{mol}^{-1}\right.$ at $248 \mathrm{~K}$ and atmospheric pressure) was assumed based on average concentrations measured during the 2009 OASIS campaign (Stephens, 2012).

$$
\left(-\frac{d\left[\mathrm{O}_{3}\right]}{d t}\right)=4.1 \times\left(2 k_{\mathrm{BrO}+\mathrm{BrO}}[\mathrm{BrO}]^{2}+\right.
$$

$\left.2 k_{\mathrm{BrO}+\mathrm{ClO}}[\mathrm{BrO}][\mathrm{ClO}]\right)$

$$
\tau_{\mathrm{O}_{3}}=\frac{\left[\mathrm{O}_{3}\right]_{\mathrm{avg}}}{4.1 \times\left(2 k[\mathrm{BrO}]^{2}+2 k[\mathrm{BrO}][\mathrm{ClO}]\right)}
$$

Because Thompson et al. (2014) utilized a temperature of $248 \mathrm{~K}$ in their model, consistent with average local temperatures at Arctic coastal sites in the springtime, we also use this temperature for our $\mathrm{BrO}$ mole fraction estimations. The rate constants $k_{\mathrm{BrO}+\mathrm{BrO}}=3.8 \times 10^{-12} \mathrm{~cm}^{3}$ molecules $^{-1} \mathrm{~s}^{-1}$ and $k_{\mathrm{BrO}+\mathrm{ClO}}=8.2 \times 10^{-12} \mathrm{~cm}^{3}$ molecules ${ }^{-1} \mathrm{~s}^{-1}$ were calculated based on Sander et al. (2011) and Atkinson et al. (2007), respectively. However, it should be noted that the rate constants change by only $\sim 7-8 \%$ when calculated at $273 \mathrm{~K}\left(k_{\mathrm{BrO}+\mathrm{BrO}}=3.5 \times 10^{-12} \mathrm{~cm}^{3}\right.$ molecules $^{-1} \mathrm{~s}^{-1}$ and $k_{\mathrm{BrO}+\mathrm{ClO}}=7.6 \times 10^{-12} \mathrm{~cm}^{3}$ molecules $\left.^{-1} \mathrm{~s}^{-1}\right)$. We also note that $k_{\mathrm{BrO}+\mathrm{ClO}}$ includes the rate constants for both Reaction (R4a) and (R4b). The calculated $\mathrm{BrO}$ mole fractions corresponding to the estimated $\tau_{\mathrm{O}_{3}}$ range from $\sim 1\left(\tau_{\mathrm{O}_{3}}=\right.$ $356 \mathrm{~h})$ to $115 \mathrm{pmol} \mathrm{mol}^{-1}\left(\tau_{\mathrm{O}_{3}}=28 \mathrm{~min}\right)$, with a median of
$16 \mathrm{pmol} \mathrm{mol}^{-1}$ (Fig. 6b). The majority of the calculated distribution of $\mathrm{BrO}$ required is fairly comparable to previously reported enhanced surface $\mathrm{BrO}$ mole fraction ranges, which often peak around 20-40 $\mathrm{pmol} \mathrm{mol}^{-1}$ (Hausmann and Platt, 1994; Hönninger et al., 2004b; Pöhler et al., 2010; Tuckermann et al., 1997). Indeed, 32 out of 38 events were calculated to require less than $40 \mathrm{pmol} \mathrm{mol}^{-1}$ of $\mathrm{BrO}$ for $\mathrm{O}_{3}$ depletion. If, however, the expected $\mathrm{BrO}$ were calculated based on Eq. (6) without the factor of 4.1 (i.e., expected $\mathrm{BrO}$ based Reactions (R3) and (R4)), this number decreases to 20 out of 38 events. For the O-Buoy1 (Barrow, AK) and O-Buoy2 deployments, MAX-DOAS BrO data are available for comparison with the calculated $\mathrm{BrO}$ estimations (Fig 6b, c; Table 3 ). Though these observed $\mathrm{BrO}$ mole fractions exhibit maxima higher than $20 \mathrm{pmol} \mathrm{mol}^{-1}$ (ex. Fig. 2), the average $\mathrm{BrO}$ mole fractions during periods of $\mathrm{O}_{3}$ decrease (ODE start time $-\mathrm{O}_{3}$ decrease stop time; Sect. 2.2) were found to be much less than $20 \mathrm{pmol} \mathrm{mol}^{-1}$ (Table 3).

The amount of $\mathrm{BrO}$ data available was dependent on the length of daylight, as the MAX-DOAS is a passive instrument (Carlson et al., 2010). In the case of O-Buoy1 at Barrow, there were not enough $\mathrm{BrO}$ data available for most periods of $\mathrm{O}_{3}$ decrease to produce solid conclusions. However, observed $\mathrm{BrO}$ levels for three events were not inconsistent with the calculated $\mathrm{BrO}$ levels required for the observed $\tau_{\mathrm{O}_{3}}$ (see Table S1 and Fig. S3 in the Supplement). While these three events do not have enough $\mathrm{BrO}$ data to merit an indepth discussion, they are discussed in more detail in the Supplement. For the remaining O-Buoy1 and all O-Buoy2 cases in which there were enough $\mathrm{BrO}$ data to make comparisons, observed $\mathrm{BrO}$ levels were found to be lower than the calculated $\mathrm{BrO}$ required by Eqs. (5) and (6), even when considering the propagated measurement error (Table 3; described in Sect. 2.1). Indeed, in two of the O-Buoy2 cases, the observed $\mathrm{BrO}$ levels are less than a tenth of that required. This result is surprising since the Arctic Ocean is the assumed originating site for ODEs. At least for O-Buoy2, the observed $\mathrm{BrO}$, assumed $6 \mathrm{pmol} \mathrm{mol}^{-1} \mathrm{ClO}$, and factor of 4.1 (Thompson et al., 2014) cannot account for the apparent $\tau_{\mathrm{O}_{3}}$.

Possible reasons for the observed small $\tau_{\mathrm{O}_{3}}$ values can be summarized by the following two hypotheses:

1. There are chemical mechanisms for $\mathrm{O}_{3}$ destruction that are currently not being considered, or other radical levels (e.g., $\mathrm{IO}, \mathrm{ClO}, \mathrm{HO}_{2}$ ) are higher than assumed here.

2. Most ODEs chemically initiate upwind of the O-Buoys such that the observed $\tau_{\mathrm{O}_{3}}$ largely result from TM, as discussed above.

Concerning the first hypothesis, iodine radical chemistry has been observed in Antarctica (Saiz-Lopez et al., 2007) and in the sub-Arctic at Hudson Bay (Mahajan et al., 2010). Models have shown that iodine chemistry has the potential to have a significant impact on $\mathrm{O}_{3}$ destruction chemistry due to the very fast rate constant for IO reaction with $\mathrm{BrO}$ 
Table 3. Average $\mathrm{BrO}$ mole fractions during periods of $\mathrm{O}_{3}$ decrease from O-Buoy2 MAX-DOAS, the corresponding propagated errors, and the estimated $\mathrm{BrO}$ required for the observed $\mathrm{O}_{3}$ depletion timescales based on Eq. (6) (Sect. 3.1; UTC - Coordinated Universal Time).

\begin{tabular}{llllll}
\hline ODE start time (UTC) & $\mathrm{O}_{3}$ decrease stop time (UTC) & $\begin{array}{l}\text { Observed } \tau_{\mathrm{O}_{3}} \\
\text { (hours) }\end{array}$ & $\begin{array}{l}\text { Average observed } \\
\mathrm{BrO}\left(\mathrm{pmol} \mathrm{mol}^{-1}\right)\end{array}$ & $\begin{array}{l}\text { Measurement uncertainty } \\
\left(\mathrm{pmol} \mathrm{mol}^{-1}\right)\end{array}$ & $\begin{array}{l}\text { Estimated BrO required } \\
\text { from observed } \\
\left.\text { pmol mol }^{-1}\right)\end{array}$ \\
\hline 15 Apr 2011 18:47 & 16 Apr 2011 06:41 & 10.5 & 7.2 & 3.5 & 17.5 \\
19 Apr 2011 04:15 & 19 Apr 2011 04:53 & 0.5 & 5.4 & 3.5 & 114.7 \\
26 Apr 2011 14:46 & 26 Apr 2011 22:29 & 16.2 & 5.2 & 3.2 & 14.8 \\
3 May 2011 11:37 & 3 May 2011 14:50 & 1.6 & 2.6 & 2.3 & 33.5 \\
6 May 2011 12:58 & 7 May 2011 21:32 & 11.8 & 5 & 3.5 & 15.1 \\
26 May 2011 21:22 & 28 May 2011 00:59 & 40.6 & 0.9 & 3.2 & 9.7 \\
\hline
\end{tabular}
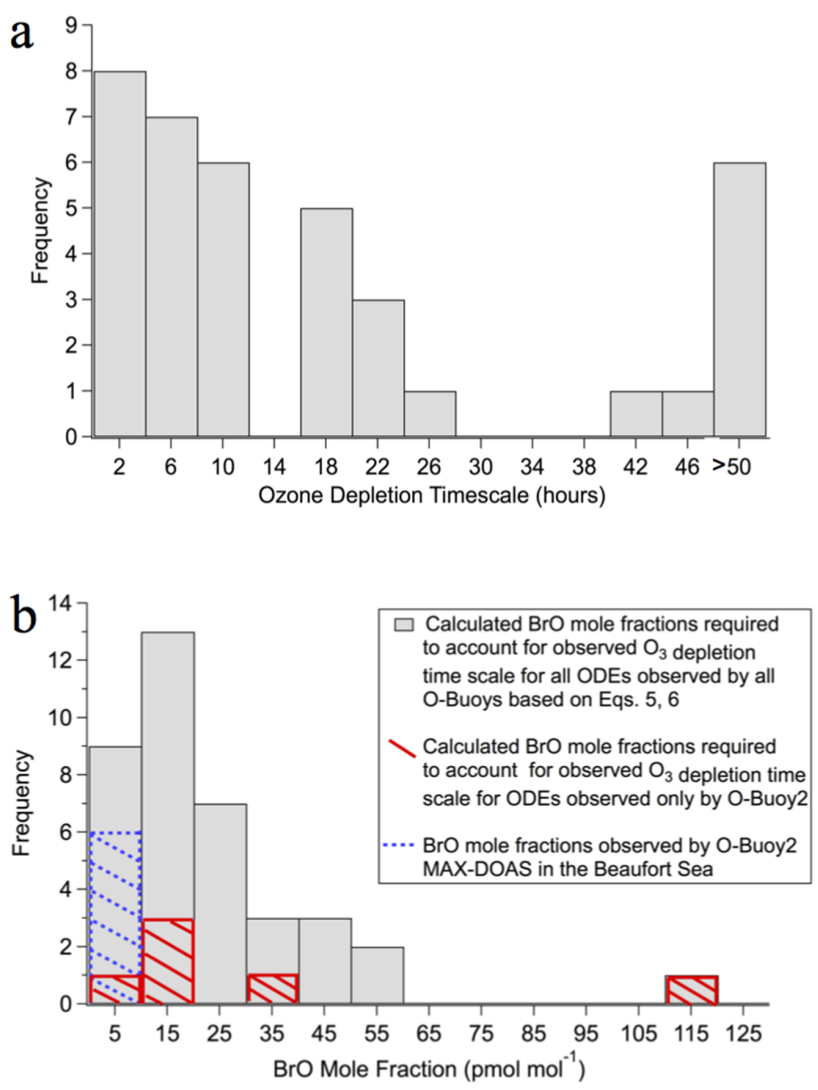

Figure 6. (a) Histogram of the calculated $\mathrm{O}_{3}$ depletion timescale distribution during ODEs. To more clearly show the majority of events, the six events with $\tau_{\mathrm{O}_{3}}$ greater than $50 \mathrm{~h}$ are grouped together on the histogram. (b) Calculated $\mathrm{BrO}$ concentrations are shown for the observed ODEs. These values were calculated using Eq. (6) with an assumed $\mathrm{ClO}$ mole fraction of $6 \mathrm{pmol} \mathrm{mol}^{-1}$ and other $\mathrm{O}_{3}$ destruction pathways (discussed in Sect. 3.1). The calculated $\mathrm{BrO}$ mole fraction mode is $15 \mathrm{pmol} \mathrm{mol}^{-1}$. Measured $\mathrm{BrO}$ for O-Buoy2 is shown as the blue hatched bar, and the corresponding $\mathrm{BrO}$ required to account for the observed ozone depletion rates for O-Buoy 2 events are shown as solid red diagonal bars.
( 32 times faster than Reaction (R3)) (Calvert and Lindberg, 2004; Atkinson et al., 2007). In a photochemical box model, Saiz-Lopez et al. (2007) found the ozone loss rate increased by a factor of four when iodine was included with bromine chemistry to destroy ozone (via $\mathrm{IO}+\mathrm{BrO}, k_{\mathrm{IO}}+\mathrm{BrO}=$ $1.2 \times 10^{-10} \mathrm{~cm}^{3}$ molecule $\mathrm{e}^{-1} \mathrm{~s}^{-1}$ at $248 \mathrm{~K}$ ). Though previous studies have indicated the presence of active iodine chemistry through enhanced levels of total iodine (Martinez et al., 1999) and filterable iodine (Barrie et al., 1994; Schall and Heumann, 1993), there are currently no measurements of IO in the high Arctic above long-path DOAS limits of detection as low as $0.3 \mathrm{pmol} \mathrm{mol}^{-1}$ (Pöhler et al., 2010), nor are there estimates of $\mathrm{I}_{2}$ mole fractions for the Arctic Ocean region. Thus, this possible mechanism remains speculative. Additionally, the enhanced salinity of first year ice could be a reason for enhanced chlorine radical production as compared to coastal (e.g., Barrow) observations, or snowpack sources of $\mathrm{HO}_{\mathrm{x}}$ (HONO (Zhou et al., 2001), HCHO (Sumner and Shepson, 1999; Sumner et al., 2002), or $\mathrm{H}_{2} \mathrm{O}_{2}$ (Hutterli et al., 2001; Jacobi et al., 2002)) could enhance $\mathrm{HO}_{2}$ levels and thus reactivity.

We can potentially test for $\mathrm{O}_{3}$ depletion chemistry missing from Eqs. (4-6) by examining the distribution of the ozone tendency, $\left(\frac{d\left[\mathrm{O}_{3}\right]}{d t}\right)$, with and without the calculated component from the chemistry included in Eq. (5). First, the observed short-term ozone tendency was calculated for values of $d t$ between consecutive $\mathrm{BrO}$ measurements (currently $\mathrm{O}$ Buoy1 at Barrow, and O-Buoy2 in the Beaufort Sea) and plotted in Fig. 7a and b. Both distributions are zero centered (average Barrow: $0.15 \mathrm{nmol} \mathrm{mol}^{-1} \mathrm{~h}^{-1}$; average Beaufort: $0.01 \mathrm{nmol} \mathrm{mol}^{-1} \mathrm{~h}^{-1}$ ) with heavy tails on each side. Then, $\frac{d\left[\mathrm{O}_{3}\right]}{d t}$ was calculated using Eq. (5), as above (Fig. 7c, d); this represents the component of the observed $\frac{d\left[\mathrm{O}_{3}\right]}{d t}$ resulting from $\mathrm{O}_{3}$ depletion chemistry. By subtracting these two results, we obtain the distribution of ozone tendencies not accounted for by the considered chemical mechanisms (Fig. 7e, f). These two distributions (representing all observations, and those with known chemistry removed) do differ significantly after this subtraction at the $95 \%$ confidence level according to the Kolmogorov-Smirnov test $(p$ value $=$ $4.9 \times 10^{-4}$ and $1.4 \times 10^{-6}$ for the O-Buoy 1 and 2 results, respectively). Both distribution averages become more shifted 

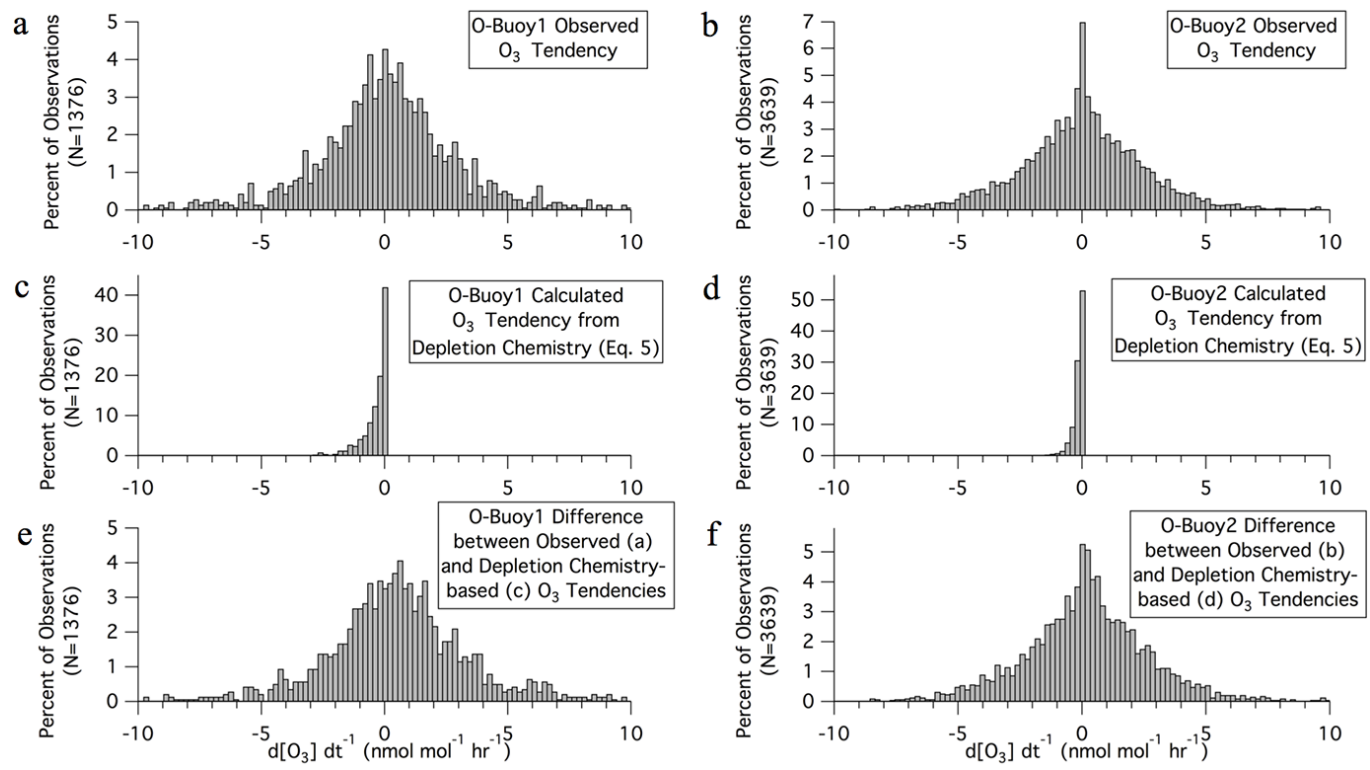

Figure 7. Histogram of the $\mathrm{O}_{3}$ tendency for observations from O-Buoy1 at Barrow, AK (a, c, e), and O-Buoy2 in the Beaufort Sea (b, d, f). (a, b) show the distributions of observed $\mathrm{O}_{3}$ tendencies between consecutive $\mathrm{BrO}$ measurement points. Middle plots (c, d) represent the $\mathrm{O}_{3}$ tendency distribution based on the depletion chemistry accounted for by Eq. (5). (e, f) result from the difference of the observed $\mathrm{O}_{3}$ tendency (a, b) and the contributions of the chemistry accounted for by Eq. (5) (c, d).

from zero, with an average $\frac{d\left[\mathrm{O}_{3}\right]}{d t}$ of $-0.43 \mathrm{nmol} \mathrm{mol}^{-1} \mathrm{~h}^{-1}$ for O-Buoy1, and $-0.18 \mathrm{nmol} \mathrm{mol}^{-1} \mathrm{~h}^{-1}$ for O-Buoy2. However, it can be shown that the overall symmetry does slightly improve after subtraction by calculating skewness (Eq. 7):

skewness $=\frac{\sum_{i=1}^{N}\left(x_{i}-\bar{x}\right)^{3}}{(N-1) s^{3}}$

where $N$ represents the number of measurements and $s$ represents the standard deviation of a sample. Skewness decreases in magnitude from -0.38 to -0.25 for the O-Buoy 1 at Barrow case, and from -0.82 to -0.80 in the O-Buoy2 in the Beaufort Sea case. Springtime chemical $\mathrm{O}_{3}$ production in the Arctic boundary layer has been found to be essentially negligible (Helmig et al., 2009; Helmig et al., 2012), and so it is likely the positive portions of these distributions result from air mass transport and vertical mixing. This analysis then produces a result not inconsistent with the idea that the remainder of the negative $\frac{d\left[\mathrm{O}_{3}\right]}{d t}$ represents air mass transport.

Hypothesis two, in which the TM dominates the observed $\tau_{\mathrm{O}_{3}}$, is in line with those of many previous studies (e.g., Bottenheim et al., 2009; Hausmann and Platt, 1994; Jacobi et al., 2010; Morin et al., 2005). As discussed in these studies, fast $\mathrm{O}_{3}$ depletion can often be attributed to changes in air mass flow, and surface $\mathrm{O}_{3}$ mole fractions can return to background levels upon the passage of low-pressure systems, with associated enhanced vertical mixing. The idea that most of the negative side of the ozone tendency distribution results from transport and not local chemistry is statistically possible only if the average spatial scale of an ODE region is below some critical size (discussed below in Sect. 3.2).

\subsection{ODE spatial scales}

To estimate the spatial scales of ODEs, we combined OBuoy observations with backward air mass trajectory model (Sect. 2.3). This analysis assumes $\mathrm{O}_{3}$ depletes within an air mass upwind via $\mathrm{CM}$, and this air mass subsequently roams across the measurement site; the size of this $\mathrm{O}_{3}$-depleted air mass can be estimated from the length of time $\mathrm{O}_{3}$ is depleted and the wind speed (i.e., TM dominates the CM at the observation site). We emphasize, however, that the observations likely involve some combination of both TM and in situ $\mathrm{CM}$, given O-Buoy measurements of $\mathrm{BrO}$ levels greater than $0 \mathrm{pmol} \mathrm{mol}^{-1}$ (indicative of active $\mathrm{O}_{3}$ depletion chemistry). It is of course conceptually possible that other transport scenarios exist; for instance, conditions could exist in some region upwind that result in the continuous depletion of $\mathrm{O}_{3}$-containing air masses that pass over this region. This depleted air may then pass over the buoy. If the depleted air remains intact, however, the spatial-scale calculations would still apply.

As shown in Fig. 8, the median of the one-dimensional length for the ODEs was $877 \mathrm{~km}$. While the estimated size distribution of the MODEs $\left(\mathrm{O}_{3}<10 \mathrm{nmol} \mathrm{mol}^{-1}\right)$ showed no clear mode, it is clear that the distribution contains mostly (relatively) smaller events, with a median size of $282 \mathrm{~km}$. The distribution of results is also consistent with observations by Jones et al. (2013) and Ridley et al. (2003), who 
a

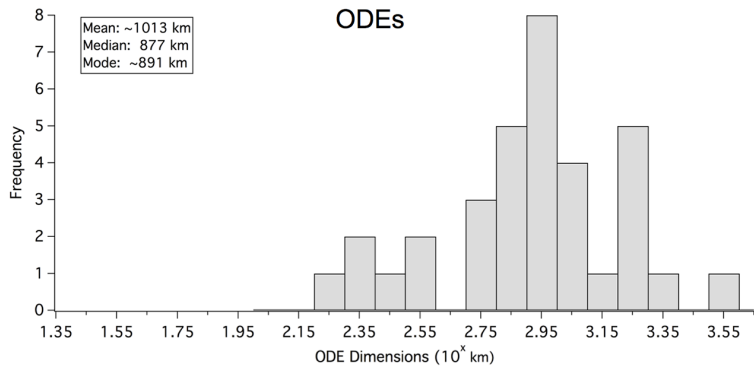

b

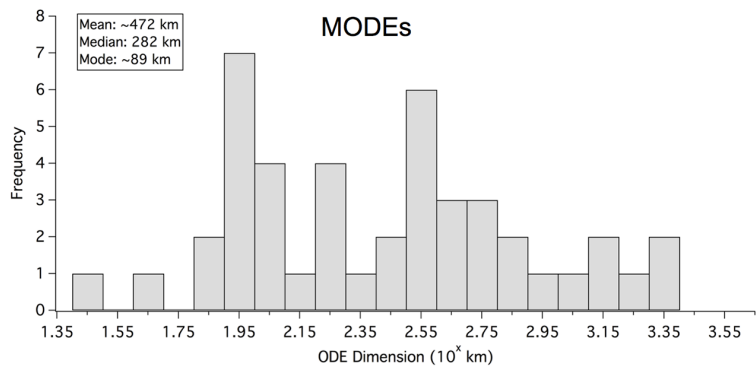

Figure 8. (a) Histogram of ODE dimensions for all ODEs. The median of the distribution is $877 \mathrm{~km}$. (b) Histogram of dimensions of MODEs. The median of the distribution is $282 \mathrm{~km}$.

both reported ODEs of spatial dimensions of at least $1200 \mathrm{~km}$ and between 600 and $900 \mathrm{~km}$, respectively. The results presented here strongly suggest that large areas of the Arctic are at least partially depleted during Arctic springtime with local embedded areas that are more depleted. While these isobaric trajectories likely represent the near-surface transport path of depleted air (Seabrook et al., 2013), we also estimated the ODE spatial scales using isentropic back trajectories (starting at $10 \mathrm{~m}$ above ground level) and the local wind speeds using the O-Buoy anemometer (Eq. 2). The means for the isobaric $(1013 \pm 379 \mathrm{~km})$, isentropic $(1260 \pm 279 \mathrm{~km})$, and local wind-speed-based $(1154 \pm 341 \mathrm{~km})$ spatial-scale distributions were statistically similar at the $95 \%$ confidence level (confidence intervals reported here). Additionally, spatialscale estimation using the distance between the isobaric trajectory start and end points yielded comparable results (mean $947 \pm 238 \mathrm{~km})$.

As discussed in Sect. 3.1, known chemical mechanisms with reasonable levels of other radicals could not account for the observed $\tau_{\mathrm{O}_{3}}$ values, suggesting these fast $\tau_{\mathrm{O}_{3}}$ values were due in large part to TM. A Monte Carlo simulation experiment was conducted with the aim of examining the statistical possibility that all observed ODEs, based on the general ODE definition $\left(\mathrm{O}_{3} \leq 15 \mathrm{nmol} \mathrm{mol}^{-1}\right)$, could have occurred upwind of the buoy and were observed because of TM. As described in Sect. 2.4, the simulations were conducted by randomly placing circles (hypothetical ODEs/source regions) across an area the size of the Arctic Ocean sea ice. These circles were defined using the distribution of ODE spatial scales determined from the 17 events observed by the OBuoy1 and O-Buoy2 deployments (Fig. S2), which observed
$\mathrm{O}_{3}$-depleted air $\sim 60 \%$ of the time between late March and May 2010 and $\sim 65 \%$ of the time between mid April and May 2011, respectively. We note that assuming circular regions for ODEs could underestimate the ODE size since it assumes the center of the event passes over the buoy, when in fact a secant is more likely. Additionally, the area could be overestimated if the true ODE shapes are actually elliptical or irregular in shape. For this statistical exercise, we made the assumptions that the circles could appear (initiate) anywhere across the Arctic Ocean, and that the circles could also represent possible sizes of ODE source regions. While there is evidence to suggest the existence of specific source regions favorable to ODE formation (Bottenheim and Chan, 2006; Bottenheim et al., 2009; Koo et al., 2012; Simpson et al., 2007a; Theys et al., 2011), no definitive conclusions have yet been made from in situ observations regarding either the locations or the sizes of such regions. We also assume that that the circle must be contained wholly within the bounds shown in Fig. 5 in order to equally represent all sizes from the distribution. We acknowledge that this assumption could overestimate the frequency with which ODEs overlap with the buoy, as ODEs have been observed in sub-Arctic regions, such as Kangerlussuaq, Greenland $\left(67^{\circ} \mathrm{N}, 51^{\circ} \mathrm{W}\right.$; Miller et al., 1997), and Hudson Bay $\left(55^{\circ} \mathrm{N}, 75^{\circ} \mathrm{W}\right.$; Hönninger et al., 2004a). However, this approach could also underestimate the frequency of overlap, as ODEs that initiate remotely from the buoy would be less likely to be part of the observed distribution of events; in other words, it is also possible that the study region for the Monte Carlo simulation could be too large. It is also assumed that the circles represent fully formed $\mathrm{O}_{3}$ depleted air masses or source regions, and that a circle overlapping with the buoy represents "local" ODE initiation relative to the O-Buoy.

The Monte Carlo simulations show that the randomly placed circles most often do not overlap with the measurement site (Fig. 9a). In fact, only very large sizes (larger than $\sim 1750 \mathrm{~km}$ ) were likely to intercept the O-buoy location with a significant probability ( $>10 \%)$, as shown in Fig. 9b. Specifically, none of the 17 circles overlapped with the OBuoy site in $58 \%$ of the 2000 simulation iterations, and only one circle (in 17) overlapped with the O-Buoy site in $33 \%$ of iterations. For the median ODE size, the probability of any individual event overlapping the Buoy was less than $1 \%$, as shown in Fig. 9b. Therefore, the spatial statistics exercise supports the possibility that the overwhelming majority of ODEs observed by the O-Buoys in the Beaufort Sea could have been observed primarily due to TM, and ODEs initiated upwind. We emphasize that this Monte Carlo exercise does not prove that this is the case, only that this hypothesis is not inconsistent with the observed ODE spatial scales. The practical question is then raised as to how many buoys (observation sites) must be present to increase the probability of observing an ODE primarily due to local chemistry (with the assumption of equal probability of initiation across the Arctic Ocean and that ODE sizes represent source regions, 

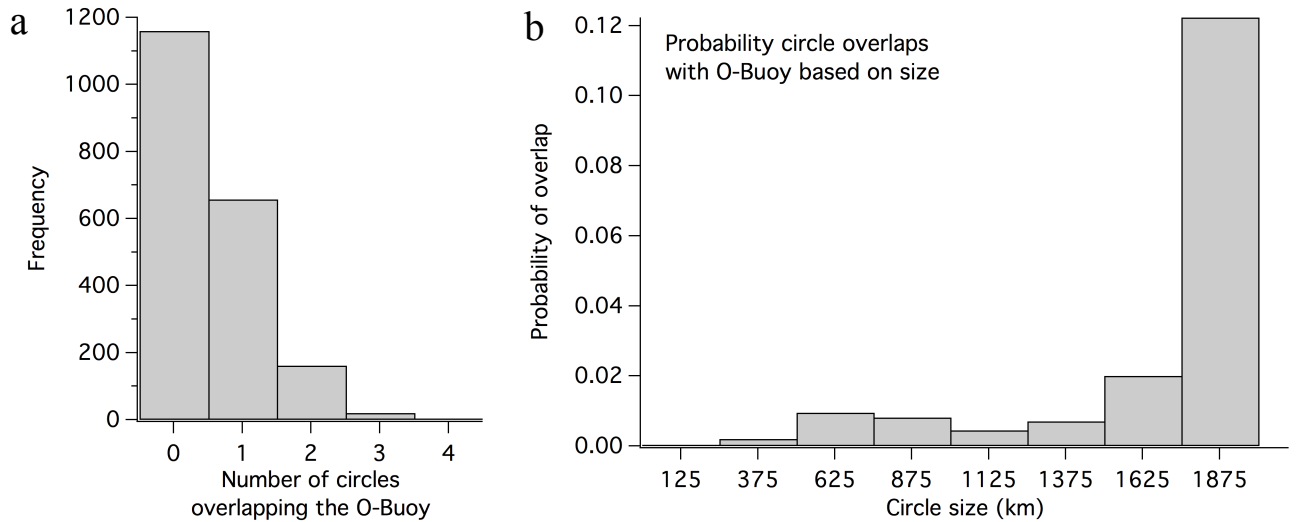

Figure 9. Results from Monte Carlo simulation experiment. (a) Based on the size distribution as defined by the ODE definition $\left(\mathrm{O}_{3} \leq 15 \mathrm{pmol} \mathrm{mol}^{-1}\right)$, circular areas were shown to not overlap with the site of the O-Buoy $58 \%$ of the time (mode $\left.=0\right)$, followed by an overlap of one circle $33 \%$ of the time. (b) Plot of the probability that an individual circle overlaps with the measurement site vs. the size of the circle.
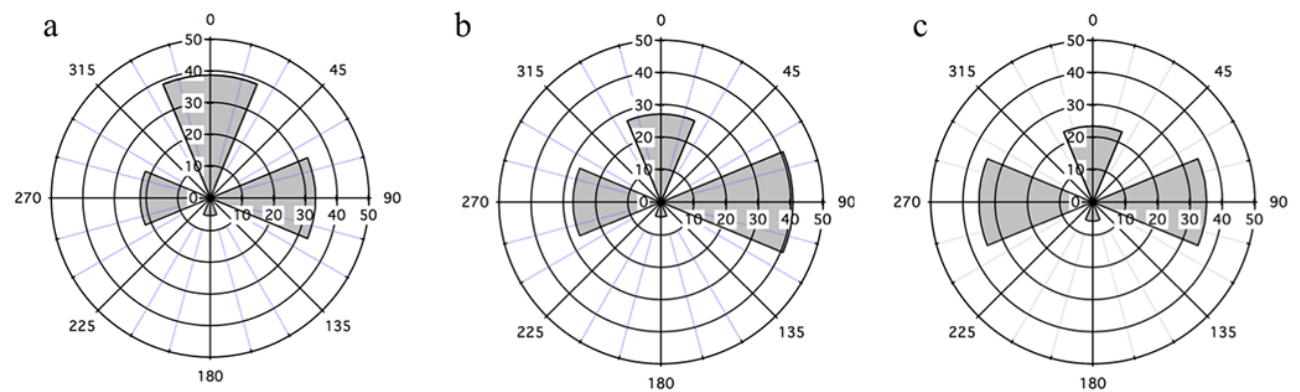

Figure 10. Wind rose plots based on the HYSPLIT backward air mass trajectories showing measured wind direction (degrees) and frequency (\%), for (a) ODEs, (b) MODEs, and (c) non-ODEs observed during the two O-Buoy Beaufort Sea deployments (see Fig. 1; Table 1).

as assumed for the Monte Carlo experiment). If, for example, two additional O-Buoys were deployed at the North Pole $\left(86^{\circ} \mathrm{N}, 54^{\circ} \mathrm{W}\right)$ and in the East Siberian Sea $\left(75^{\circ} \mathrm{N}, 170^{\circ} \mathrm{E}\right)$, both potential sites of future O-Buoy deployments, repeating the simulations showed that five out of 17 circles overlapped with at least one measurement site, with no simulation iterations resulting in zero circle overlaps (Fig. S4). This result emphasizes the need for multiple, simultaneous deployments of O-Buoys across different geographical regions to ensure that local-scale chemistry is observed within one deployment season.

To examine if there is a consistent upwind region from which ODEs travel, wind rose plots were constructed for the ODEs observed by O-Buoy1 (2010 deployment) and OBuoy2 in the Beaufort Sea, as shown in Fig. 10. As above, the O-Buoys deployed in the Beaufort Sea were chosen because of their similar locations and drift trajectories, providing the needed statistics for the analysis. During ODEs (Fig. 10a), air masses most commonly traveled from the north ( $39 \%$ of cases), followed by those from the east ( $\sim 33 \%$ of cases) and the west ( $\sim 22 \%$ of cases). For the MODE air masses, the trajectories most often originated from the eastern sec- tor ( $\sim 41 \%$ of cases; Fig. $10 \mathrm{~b})$, and the northern and western sectors accounted for $\sim 27 \%$ of cases each. Finally for cases in which $\mathrm{O}_{3}$ was not depleted (non-ODE cases; Fig. 10c), the eastern and western sectors each accounted for $35 \%$ of cases, and the north accounted for $24 \%$. Only one event in each case showed an air mass originating from the south, toward the Alaskan and Canadian coasts. The results presented are consistent with a hypothesis that all regions that are sea-ice covered can support ODE chemistry. Notably, the region to the east of the buoys (i.e., from the Canadian archipelago and eastern Beaufort Sea) features sea ice that historically contains a high fraction of multiyear ice (Kwok et al., 2009), and GOME satellite imagery has previously shown large amounts of $\mathrm{BrO}$ to be present in this region (Choi et al., 2012; Koo et al., 2012; Richter et al., 1998; Salawitch et al., 2010). Using backward air mass trajectories originating from the coastal sites of Alert, Canada, and Zeppelinfjellet, Svalbard, Bottenheim and Chan (2006) suggested that ODE air mass source regions could be in the East Siberian Sea, an area to the northwest of the O-Buoys that features first-year ice that breaks up in spring. It should be noted, however, that Bottenheim and Chan (2006) only reported trends during the month of 
a
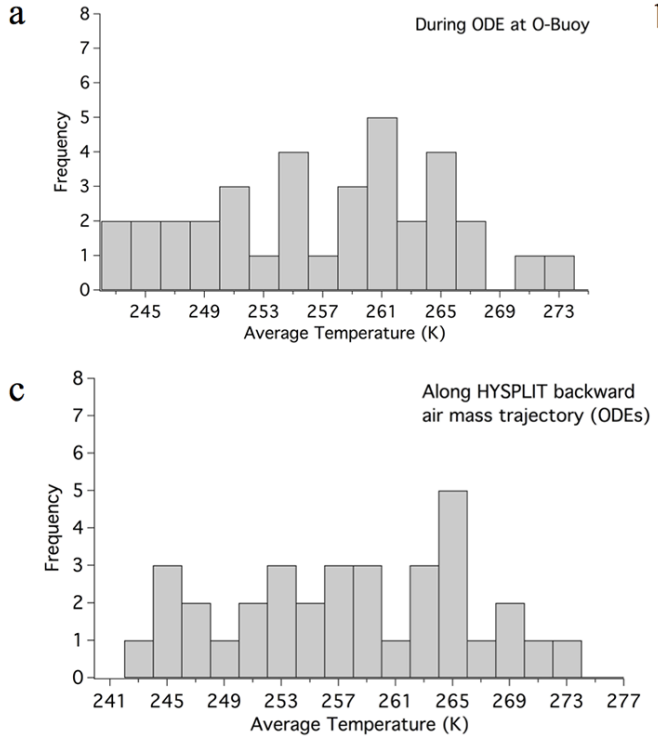

b
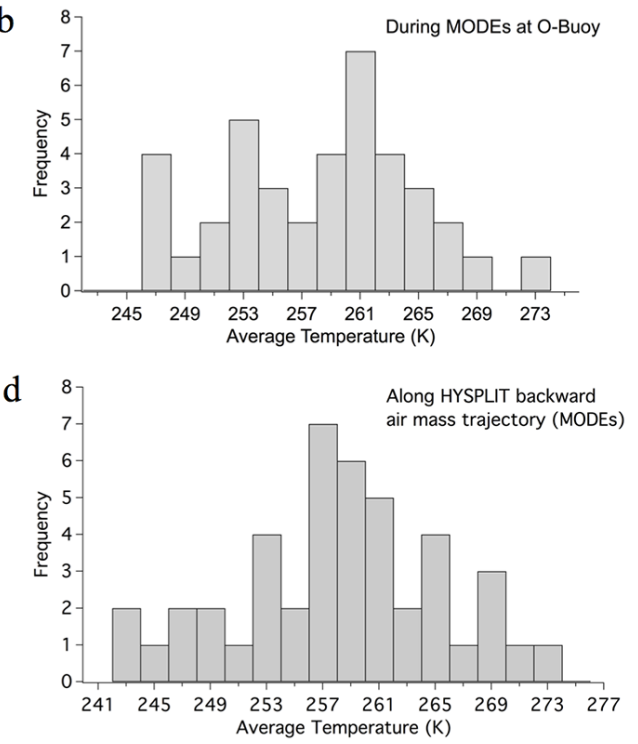

Figure 11. Histograms of the average ambient temperature measured by the O-Buoys during (a) ODEs and (b) MODEs. Histograms of the average temperature along the HYSPLIT backward air mass trajectories for (c) ODEs and (d) MODEs.

April, as opposed to this study that examined ODEs from as early as February to as late as June (Table 1 and Fig. 2). Unfortunately, there were not enough events per month here to observe any clear monthly source region trends. Additionally, while the ODE and MODE cases show slight preferences for northern or eastern winds, respectively, the nonODE cases do not appear to differ significantly from the ODE and MODE cases. As recently presented by Moore et al. (2014), it is also possible that $\mathrm{O}_{3}$ recovers when air passes over open sea ice leads due to convective mixing, and air that passed over unbroken ice was more often $\mathrm{O}_{3}$-depleted, and thus local sea ice conditions could have a more direct impact on $\mathrm{O}_{3}$ levels than the wind direction.

\subsection{Temperature and wind speed during ODEs}

Figure 11 shows the distribution of average temperatures that applied during the ODEs in this study. Local average temperatures during ODEs ranged between 243 and $273 \mathrm{~K}$ (Fig. 11a; median $257 \mathrm{~K}$ ). The apparent mode of the distribution $(261 \mathrm{~K})$ is $8 \mathrm{~K}$ warmer than the hypothesized required upper limit temperature for rapid ozone depletion $(253 \mathrm{~K})$. Indeed, $\sim 66 \%$ of the ODEs occurred at average temperatures greater than $253 \mathrm{~K}$. An illustrative event is shown in Fig. 2; the O-Buoy2 ODE occurring in early June shows a noticeable increase in $\mathrm{BrO}$ while temperatures average around $270 \mathrm{~K}$. The temperatures for MODEs resulted in a similar distribution (Fig. 11b). If, however, ODEs most often originate upwind from the site of O-Buoys, the local temperatures could be irrelevant, as the actual depletion chemistry may have taken place at a location where the temperature was much lower. To examine this, the isobaric HYSPLIT backward air mass trajectories were utilized to estimate the average temperatures experienced by the observed air mass upwind. In Fig. 11c and d, we present histograms of the average temperatures from each air mass trajectory for both ODEs and MODEs, which were observed to be very similar (medians: $\sim 258$ and $257 \mathrm{~K}$ for ODE and MODE, respectively) and not significantly different from those measured at the O-Buoys. As with the local observations, approximately two-thirds of the trajectory temperature averages were above $253 \mathrm{~K}$, though we acknowledge that there is a high level of uncertainty associated with using an air mass back trajectory model for such a purpose in a data sparse region (Kahl, 1993). Additionally, we analyzed the minimum temperatures observed by the O-Buoy and from HYSPLIT trajectories during the same depletion periods. The median minimum temperatures observed at the O-Buoy are 251 and $253 \mathrm{~K}$ for the ODE and MODE cases, respectively. Similarly, the median minimum temperatures obtained from HYSPLIT trajectories are 250 and $254 \mathrm{~K}$ for the ODE and MODE cases, respectively. In both cases, it is interesting that only about half of the events were observed with minimum temperatures less than the eutectic temperature of $\mathrm{NaCl}(252 \mathrm{~K})$, consistent with the results above. This analysis reveals no apparent temperature dependence for $\mathrm{O}_{3}$ depletion and shows that temperatures below $253 \mathrm{~K}$ were not necessary to observe ozonedepleted air masses, corroborating the conclusions of Bottenheim et al. (2009) and Jacobi et al. (2010).

Recent reports discuss the possibility that ODEs can be initiated after blowing snow events (Frieß et al., 2011; Jones et al., 2009; Yang et al., 2008; Yang et al., 2010), which presumably produce the availability of new saline surfaces, whether in suspended aerosol form, or through 

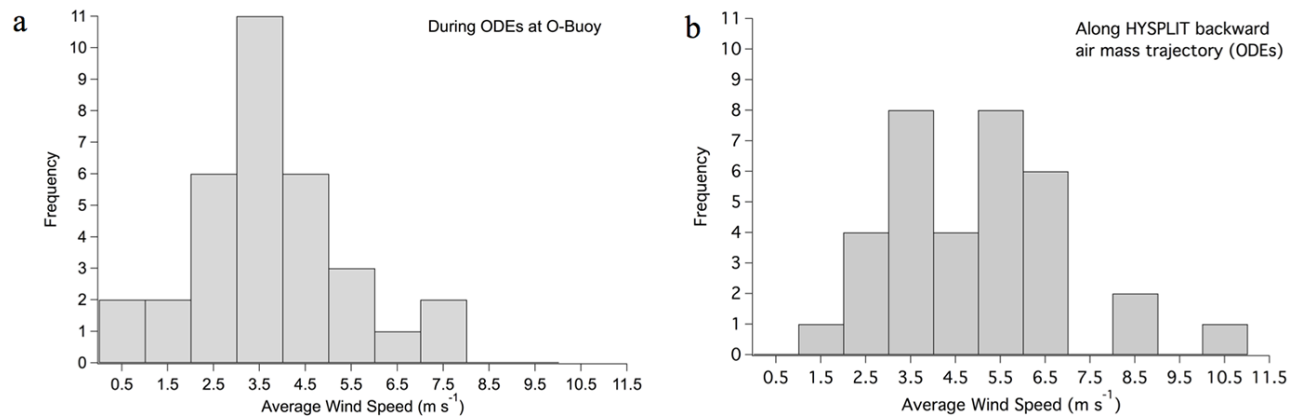

Figure 12. (a) Histogram of the average wind speed measured by the O-Buoys during ODEs. (b) Histogram of average wind speeds from $\mathrm{O}_{3}$-depleted air masses, as determined from the HYSPLIT backward air mass trajectories.

redeposition of sea salt aerosol to the physical surface. Blowing snow events occur during periods of higher wind speeds $\left(>8 \mathrm{~m} \mathrm{~s}^{-1}\right.$ ) (Frieß et al., 2011), implying that there might be a relationship between wind speed and ODEs. We thus performed an analysis for wind speeds analogous to the temperatures using both local O-Buoy data and HYSPLIT backward trajectories. Figure 12a shows that ODEs observed at the O-Buoy were characterized by low measured wind speeds (median of $3.6 \mathrm{~m} \mathrm{~s}^{-1}$ and a mode of $3.5 \mathrm{~m} \mathrm{~s}^{-1}$ ), relative to what is needed for blowing snow. However, there is also a difficulty in this analysis in that, under these circumstances, when the air is most of the time at least partly depleted, such a histogram may reflect, at least in part, the normal distribution of wind speeds found in the Arctic troposphere. Therefore, for comparison, periods when $\mathrm{O}_{3}$ was not depleted (non-ODEs) were examined (see Supplement). As shown in Fig. S5, there was no apparent difference in the modes for non-ODEs relative to the depleted cases. We reiterate that the O-Buoy wind speed measurements reported here could be biased low (see Sect. 2.1); thus, we compare this distribution to one determined by the HYSPLIT method (described in the Supplement) below.

The distribution of average wind speeds along the HYSPLIT trajectories (Fig. 12b) reveals a faster median wind speed of $4.9 \mathrm{~m} \mathrm{~s}^{-1}$, potentially consistent with ODEs occurring at somewhat higher wind speeds. However, the distribution showed no clear preference for higher wind speeds for ODEs. During non-ODE periods, we found the majority of wind speeds to be between 3 and $6 \mathrm{~m} \mathrm{~s}^{-1}$, similar to that for the ODE cases (Fig. S5b in the Supplement), showing that the wind speeds characterizing the upwind air masses observed for ODEs are not different from those for nondepleted conditions. From this analysis, we found that elevated wind speed appeared to be neither a prerequisite, nor a defining characteristic for ODEs, as also found by Helmig et al. (2012) and Solberg et al. (1996).

\section{Conclusions}

The O-Buoy was developed in part to enable the observation of ODEs at the hypothesized location of their initiation, the frozen Arctic Ocean surface. Surface measurements of ambient $\mathrm{O}_{3}, \mathrm{BrO}$, temperature, and wind speed from five separate O-Buoy deployments were utilized to gain insights into the characteristics of ODEs observed over the Arctic Ocean.

The apparent timescales of $\mathrm{O}_{3}$ depletion during ODEs, based on both CM and TM, were calculated to be shorter (median of $11 \mathrm{~h}$ ) than previous modeled chemical estimates (e.g., Hausmann and Platt, 1994) by a factor of two or more. This observation suggests the $\mathrm{O}_{3}$ depletion timescales are dominated by TM, accelerated chemical mechanisms involving higher radical levels, or novel chemical mechanisms. If TM are assumed to dominate local observations, spatially, the majority of the Arctic Ocean marine boundary layer is likely at least partially depleted in $\mathrm{O}_{3}$ during spring, suggesting that $\mathrm{O}_{3}$-depleted air masses remain intact for long periods of time after halogen chemistry has subsided. Regions of MODEs $\left(\mathrm{O}_{3}<10 \mathrm{nmol} \mathrm{mol}^{-1}\right)$ were, on average, smaller, with a median of $282 \mathrm{~km}$, compared to a median of $877 \mathrm{~km}$ for ODEs $\left(\mathrm{O}_{3} \leq 15 \mathrm{nmol} \mathrm{mol}^{-1}\right)$. An expanded network of $\mathrm{O}_{3}$ monitors across the Arctic Ocean is required to effectively capture the spatial extent of the small, actively $\mathrm{O}_{3}$-depleting air masses, as well as that of the larger, depleted air masses. Monte Carlo simulations supported the possibility that these spatial ODE sizes are consistent with depletion upwind of the O-Buoy, followed by air mass transport to the buoy. However, the degree to which process dominates local observations of ODEs (TM vs. CM) is unknown, as O-Buoy observations of $\mathrm{BrO}$ indicate that there is generally always some degree of chemistry involved. Thus, to further address the question of the $\mathrm{O}_{3}$ depletion timescales, more long-term $\mathrm{O}_{3}$ and halogen measurements over the Arctic Ocean sea ice are necessary, particularly in locations such as the East Siberian and Chukchi seas.

There was no apparent temperature dependence observed for the presence of an ODE, and low temperatures (i.e., less than $253 \mathrm{~K}$ ) were not required for the observation of an 
ODE. The distribution of wind speeds local to the O-Buoy was moderately low during ODEs (mode of $\sim 3.5 \mathrm{~m} \mathrm{~s}^{-1}$ ), showing that ODEs were primarily observed under relatively calm conditions. While higher average wind speeds (median $\sim 5 \mathrm{~m} \mathrm{~s}^{-1}$ ) were estimated for the course of the backward air mass trajectory, we did not observe a clear preference for ODEs occurring during higher wind speeds. Concurrent measurements of blowing snow, sea salt aerosol, ozone, and halogens, in addition to wind speed, are required to better understand the relationship between wind speed and ODEs.

\section{The Supplement related to this article is available online at doi:10.5194/acp-14-4875-2014-supplement.}

Acknowledgements. The authors thank the NSF for the funding of both the development and deployments of the O-Buoys (grants ARC-0612331, ARC-0611992, ARC-0612047, and ARC-0612457 to P. A. Matrai, D. K. Perovich, P. B. Shepson, and W. R. Simpson, respectively), as well as for the NSF Postdoctoral Fellowship for Polar Regions Research for K. A. Pratt. Additionally, we are thankful for additional funding for O-Buoys provided by the Government of Canada Program for the International Polar Year, as part of OASIS-CANADA (Project no. MD065). We would like to also thank U. Frieß and J. Zielke at the University of Heidelberg for assistance with the inversion of the MAX-DOAS data. The authors gratefully thank the NOAA Air Resources Laboratory (ARL) for the provision of the HYSPLIT transport and dispersion model used in this publication, as well as the National Snow and Ice Data Center for providing access to monthly sea ice extent data. The authors are grateful to the O-Buoy* team, without whom this project would not have been possible. *The current O-Buoy team includes M. Carlsen, F. Chavez, M. Everly, G. Friederich, P. Joyce, R. Oglesbee, C. Rauschenberg, A. Sheppard, R. Stehle, B. Tupper, T. Valentic, C. Wahl, C. Williams, P. Wyss, and J. Zimmerman.

Edited by: R. Sander

\section{References}

Abbatt, J. P. D., Thomas, J. L., Abrahamsson, K., Boxe, C., Granfors, A., Jones, A. E., King, M. D., Saiz-Lopez, A., Shepson, P. B., Sodeau, J., Toohey, D. W., Toubin, C., von Glasow, R., Wren, S. N., and Yang, X.: Halogen activation via interactions with environmental ice and snow in the polar lower troposphere and other regions, Atmos. Chem. Phys., 12, 6237-6271, doi:10.5194/acp-12-6237-2012, 2012.

Adams, J. W., Holmes, N. S., and Crowley, J. N.: Uptake and reaction of $\mathrm{HOBr}$ on frozen and dry $\mathrm{NaCl} / \mathrm{NaBr}$ surfaces between 253 and 233 K, Atmos. Chem. Phys., 2, 79-91, doi:10.5194/acp2-79-2002, 2002.

Aguzzi, A. and Rossi, M. J.: Heterogeneous hydrolysis and reaction of $\mathrm{BrONO}_{2}$ and $\mathrm{Br}_{2} \mathrm{O}$ on pure ice and ice doped with $\mathrm{HBr}$, J. Phys. Chem. A, 106, 5891-5901, doi:10.1021/Jp014383e, 2002.

Albert, M. R., Grannas, A. M., Bottenheim, J., Shepson, P. B., and Perron, F. E.: Processes and properties of snow-air transfer in the high Arctic with application to interstitial ozone at Alert,
Canada, Atmos. Environ., 36, 2779-2787, doi:10.1016/s13522310(02)00118-8, 2002.

Anlauf, K. G., Mickle, R. E., and Trivett, N. B. A.: Measurement of Ozone during Polar Sunrise Experiment 1992, J. Geophys. Res., 99, 25345-25353, doi:10.1029/94jd01312, 1994.

Atkinson, R., Baulch, D. L., Cox, R. A., Crowley, J. N., Hampson, R. F., Hynes, R. G., Jenkin, M. E., Rossi, M. J., and Troe, J.: Evaluated kinetic and photochemical data for atmospheric chemistry: Volume III - gas phase reactions of inorganic halogens, Atmos. Chem. Phys., 7, 981-1191, doi:10.5194/acp-7-981-2007, 2007.

Barrie, L. A., Bottenheim, J. W., Schnell, R. C., Crutzen, P. J., and Rasmussen, R. A.: Ozone Destruction and PhotochemicalReactions at Polar Sunrise in the Lower Arctic Atmosphere, Nature, 334, 138-141, 1988.

Barrie, L. A., Staebler, R., Toom, D., Georgi, B., Denhartog, G., Landsberger, S., and Wu, D.: Arctic Aerosol Size-Segregated Chemical Observations in Relation to Ozone Depletion during Polar Sunrise Experiment 1992, J. Geophys. Res., 99, 2543925451, doi:10.1029/94jd01514, 1994.

Bottenheim, J. W., Gallant, A. G., and Brice, K. A.: Measurements of $\mathrm{NO}_{y}$ species and $\mathrm{O}_{3}$ at $82^{\circ} \mathrm{N}$ latitude, Geophys. Res. Lett. 13, 113-116, doi:10.1029/GL013i002p00113, 1986.

Bottenheim, J. W., Fuentes, J. D., Tarasick, D. W., and Anlauf, K. G.: Ozone in the Arctic lower troposphere during winter and spring 2000 (ALERT2000), Atmos. Environ., 36, 2535-2544, doi:10.1016/s1352-2310(02)00121-8, 2002.

Bottenheim, J. W. and Chan, E.: A trajectory study into the origin of spring time Arctic boundary layer ozone depletion, J. Geophys. Res., 111, D19301, doi:10.1029/2006jd007055, 2006.

Bottenheim, J. W., Netcheva, S., Morin, S., and Nghiem, S. V.: Ozone in the boundary layer air over the Arctic Ocean: measurements during the TARA transpolar drift 2006-2008, Atmos. Chem. Phys., 9, 4545-4557, doi:10.5194/acp-9-4545-2009, 2009.

Boudries, H. and Bottenheim, J. W.: $\mathrm{Cl}$ and $\mathrm{Br}$ atom concentrations during a surface boundary layer ozone depletion event in the Canadian high Arctic, Geophys. Res. Lett., 27, 517-520, doi:10.1029/1999gl011025, 2000.

Calvert, J. G. and Lindberg, S. E.: Potential influence of iodinecontaining compounds on the chemistry of the troposphere in the polar spring. I. Ozone depletion, Atmos. Environ., 38, 50875104, doi:10.1016/j.atmosenv.2004.05.049, 2004.

Carlson, D., Donohoue, D., Platt, U., and Simpson, W. R.: A low power automated MAX-DOAS instrument for the Arctic and other remote unmanned locations, Atmos. Meas. Tech., 3, 429439, doi:10.5194/amt-3-429-2010, 2010.

Cavender, A. E., Biesenthal, T. A., Bottenheim, J. W., and Shepson, P. B.: Volatile organic compound ratios as probes of halogen atom chemistry in the Arctic, Atmos. Chem. Phys., 8, $1737-$ 1750, doi:10.5194/acp-8-1737-2008, 2008.

Cho, H., Shepson, P. B., Barrie, L. A., Cowin, J. P., and Zaveri, R.: NMR investigation of the quasi-brine layer in ice/brine mixtures, J. Phys. Chem. B, 106, 11226-11232, doi:10.1021/Jp020449, 2002.

Choi, S., Wang, Y., Salawitch, R. J., Canty, T., Joiner, J., Zeng, T., Kurosu, T. P., Chance, K., Richter, A., Huey, L. G., Liao, J., Neuman, J. A., Nowak, J. B., Dibb, J. E., Weinheimer, A. J., Diskin, G., Ryerson, T. B., da Silva, A., Curry, J., Kinnison, D., Tilmes, S., and Levelt, P. F.: Analysis of satellite-derived Arctic tropo- 
spheric $\mathrm{BrO}$ columns in conjunction with aircraft measurements during ARCTAS and ARCPAC, Atmos. Chem. Phys., 12, 12551285, doi:10.5194/acp-12-1255-2012, 2012.

Deutschmann, T., Beirle, S., Frieß, U., Grzegorski, M., Kern, C., Kritten, L., Platt, U., Prados-Román, C., Puksite, J., Wagner, T., Werner, B., and Pfeilsticker, K.: The Monte Carlo atmospheric radiative transfer model McArtim: Introduction and validation of Jacobians and 3D features, J. Quant. Spectrosc. Radiat. Transfer, 112, 1119-1137, 2011.

Draxler, R. R. and Hess, G. D.: Description of the HYSPLIT 4 modeling system. NOAA Tech. Memo. ERL ARL-224, NOAA Air Resources Laboratory, Silver Spring, MD, 1997.

Draxler, R. R. and Hess, G. D.: An overview of the HYSPLIT 4 modeling system of trajectories, dispersion, and deposition, Aust. Meteor. Mag., 47, 295-308, 1998.

Draxler, R. R.: HYSPLIT 4 users's guide, U.S. Dept. of Commerce, National Oceanic and Atmospheric Administration, Environmental Research Laboratories, Air Resources Laboratory, Silver Spring, MD, 1-209, 1999.

Fan, S. M. and Jacob, D. J.: Surface Ozone Depletion in Arctic Spring Sustained by Bromine Reactions on Aerosols, Nature, 359, 522-524, doi:10.1038/359522a0, 1992.

Fayt, C., De Smedt, I., Letocart, V., Merlaud, A., Pinardi, G., and Van Roozendael, M.: QDOAS Software User Manual, Belgian Institute for Space Aeronomy, 2011.

Foster, K. L., Plastridge, R. A., Bottenheim, J. W., Shepson, P. B., Finlayson-Pitts, B. J., and Spicer, C. W.: The role of $\mathrm{Br}_{2}$ and $\mathrm{BrCl}$ in surface ozone destruction at polar sunrise, Science, 291, 471-474, doi:10.1126/science.291.5503.471, 2001.

Frieß, U., Monks, P. S., Remedios, J. J., Rozanov, A., Sinreich, R., Wagner, T., and Platt, U.: MAX-DOAS $\mathrm{O}_{4}$ measurements: A new technique to derive information on atmospheric aerosols: 2. Modeling studies, J. Geophys. Res., 111, D14203, doi:10.1029/2005JD006618, 2006..

Frieß, U., Sihler, H., Sander, R., Pöhler, D., Yilmaz, S., and Platt, U.: The vertical distribution of $\mathrm{BrO}$ and aerosols in the Arctic: Measurements by active and passive differential optical absorption spectroscopy, J. Geophys. Res., 116, D00R04, doi:10.1029/2011JD015938, 2011.

Gauss, M., Myhre, G., Isaksen, I. S. A., Grewe, V., Pitari, G., Wild, O., Collins, W. J., Dentener, F. J., Ellingsen, K., Gohar, L. K., Hauglustaine, D. A., Iachetti, D., Lamarque, J. F., Mancini, E., Mickley, L. J., Prather, M. J., Pyle, J. A., Sanderson, M. G., Shine, K. P., Stevenson, D. S., Sudo, K., Szopa, S., and Zeng, G.: Radiative forcing since preindustrial times due to ozone change in the troposphere and the lower stratosphere, Atmos. Chem. Phys., 6, 575-599, doi:10.5194/acp-6-575-2006, 2006.

Gilman, J. B., Burkhart, J. F., Lerner, B. M., Williams, E. J., Kuster, W. C., Goldan, P. D., Murphy, P. C., Warneke, C., Fowler, C., Montzka, S. A., Miller, B. R., Miller, L., Oltmans, S. J., Ryerson, T. B., Cooper, O. R., Stohl, A., and de Gouw, J. A.: Ozone variability and halogen oxidation within the Arctic and sub-Arctic springtime boundary layer, Atmos. Chem. Phys., 10, 10223-10236, doi:10.5194/acp-10-10223-2010, 2010.

Hanson, D. R. and Ravishankara, A. R.: Heterogeneous Chemistry of Bromine Species in Sulfuric-Acid under Stratospheric Conditions, Geophys. Res. Lett., 22, 385-388, doi:10.1029/94GL03379, 1995.
Hausmann, M. and Platt, U.: Spectroscopic measurement of bromine oxide and ozone in the high Arctic during Polar Sunrise Experiment 1992, J. Geophys. Res., 99, 25399-25413, doi:10.1029/94jd01314, 1994.

Helmig, D., Cohen, L. D., Bocquet, F., Oltmans, S., Grachev, A. and Neff, W.: Spring and summertime diurnal surface ozone fluxes over the polar snow at Summit, Greenland, Geophys. Res. Lett., 36, L08809, doi:10.1029/2008GL036549, 2009.

Helmig, D., Boylan, P., Johnson, B., Oltmans, S., Fairall, C., Staebler, R., Weinheimer, A., Orlando, J., Knapp, D. J., Montzka, D. D., Flocke, F., Frieß, U., Sihler, H., and Shepson, P. B.: Ozone dynamics and snow-atmosphere exchanges during ozone depletion events at Barrow, Alaska, J. Geophys. Res., 117, D20303, doi:10.1029/2012jd017531, 2012.

Hönninger, G., Leser, H., Sebastián, O., and Platt, U.: Ground-based measurements of halogen oxides at the Hudson Bay by active longpath DOAS and passive MAX-DOAS, Geophys. Res. Lett., 31, L04111, doi:10.1029/2003GL018982, 2004a.

Hönninger, G., von Friedeburg, C., and Platt, U.: Multi axis differential optical absorption spectroscopy (MAX-DOAS), Atmos. Chem. Phys., 4, 231-254, doi:10.5194/acp-4-231-2004, 2004b.

Hopper, J. F., Peters, B., Yokouchi, Y., Niki, H., Jobson, B. T., Shepson, P. B., and Muthuramu, K.: Chemical and Meteorological Observations at Ice Camp Swan during Polar Sunrise Experiment 1992, J. Geophys. Res., 99, 25489-25498, doi:10.1029/94JD02303, 1994.

Hopper, J. F., Barrie, L. A., Silis, A., Hart, W., Gallant, A. J., and Dryfhout, H.: Ozone and meteorology during the 1994 Polar Sunrise Experiment, J. Geophys. Res., 103, 1481-1492, 1998.

Huff, A. K., and Abbatt, J. P. D.: Kinetics and product yields in the heterogeneous reactions of $\mathrm{HOBr}$ with ice surfaces containing $\mathrm{NaBr}$ and $\mathrm{NaCl}$, J. Phys. Chem. A, 106, 5279-5287, doi:10.1021/Jp014296m, 2002.

Hutterli, M. A., McConnell, J. R., Stewart, R. W., Jacobi, H. W., and Bales, R. C.: Impact of temperature-driven cycling of hydrogen peroxide $\left(\mathrm{H}_{2} \mathrm{O}_{2}\right)$ between air and snow on the planetary boundary layer, J. Geophys. Res., 106, 15395-15404, doi:10.1029/2001jd900102, 2001.

Jacobi, H. W., Frey, M. M., Hutterli, M. A., Bales, R. C., Schrems, O., Cullen, N. J., Steffen, K., and Koehler, C.: Measurements of hydrogen peroxide and formaldehyde exchange between the atmosphere and surface snow at Summit, Greenland, Atmos. Environ., 36, 2619-2628, doi:10.1016/S1352-2310(02)00106-1, 2002.

Jacobi, H. W., Kaleschke, L., Richter, A., Rozanov, A., and Burrows, J. P.: Observation of a fast ozone loss in the marginal ice zone of the Arctic Ocean, J. Geophys. Res., 111, D15309, doi:10.1029/2005jd006715, 2006.

Jacobi, H. W., Morin, S., and Bottenheim, J. W.: Observation of widespread depletion of ozone in the springtime boundary layer of the central Arctic linked to mesoscale synoptic conditions, J. Geophys. Res., 115, D17302, doi:10.1029/2010jd013940, 2010.

Jaeschke, W., Salkowski, T., Dierssen, J. P., Trumbach, J. V., Krischke, U., and Günther, A.: Measurements of trace substances in the Arctic troposphere as potential precursors and constituents of Arctic haze, J. Atmos. Chem., 34, 291-319, 1999.

Jobson, B. T., Niki, H., Yokouchi, Y., Bottenheim, J., Hopper, F., and Leaitch, R.: Measurements of $\mathrm{C}_{2}-\mathrm{C}_{6}$ Hydrocarbons during the Polar Sunrise 1992 Experiment - Evidence for $\mathrm{Cl}$ atom 
and $\mathrm{Br}$ atom Chemistry, J. Geophys. Res., 99, 25355-25368, doi:10.1029/94JD01243, 1994.

Jones, A. E., Anderson, P. S., Begoin, M., Brough, N., Hutterli, M. A., Marshall, G. J., Richter, A., Roscoe, H. K., and Wolff, E. W.: $\mathrm{BrO}$, blizzards, and drivers of polar tropospheric ozone depletion events, Atmos. Chem. Phys., 9, 4639-4652, doi:10.5194/acp-94639-2009, 2009.

Jones, A. E., Wolff, E. W., Brough, N., Bauguitte, S. J. B., Weller, R., Yela, M., Navarro-Comas, M., Ochoa, H. A., and Theys, N.: The spatial scale of ozone depletion events derived from an autonomous surface ozone network in coastal Antarctica, Atmos. Chem. Phys., 13, 1457-1467, doi:10.5194/acp-13-1457-2013, 2013.

Kahl, J. D.: A Cautionary Note on the Use of Air Trajectories in Interpreting Atmospheric Chemistry Measurements, Atmos. Environ., Part A, 27, 3037-3038, 1993.

Knepp, T. N., Bottenheim, J., Carlsen, M., Carlson, D., Donohoue, D., Friederich, G., Matrai, P. A., Netcheva, S., Perovich, D. K., Santini, R., Shepson, P. B., Simpson, W., Valentic, T., Williams, C., and Wyss, P. J.: Development of an autonomous sea ice tethered buoy for the study of ocean-atmosphere-sea ice-snow pack interactions: the O-buoy, Atmos. Meas. Tech., 3, 249-261, doi:10.5194/amt-3-249-2012, 2010.

Koo, J. H., Wang, Y., Kurosu, T. P., Chance, K., Rozanov, A., Richter, A., Oltmans, S. J., Thompson, A. M., Hair, J. W., Fenn, M. A., Weinheimer, A. J., Ryerson, T. B., Solberg, S., Huey, L. G., Liao, J., Dibb, J. E., Neuman, J. A., Nowak, J. B., Pierce, R. B., Natarajan, M., and Al-Saadi, J.: Characteristics of tropospheric ozone depletion events in the Arctic spring: analysis of the ARCTAS, ARCPAC, and ARCIONS measurements and satellite BrO observations, Atmos. Chem. Phys., 12, 9909-9922, doi:10.5194/acp-12-9909-2012, 2012.

Kwok, R., Cunningham, G. F., Wensnahan, M., Rigor, I., Zwally, H. J., and Yi, D.: Thinning and volume loss of the Arctic Ocean sea ice cover: 2003-2008, J. Geophys. Res., 114, C07005, doi:10.1029/2009JC005312, 2009.

Le Bras, G. and Platt, U.: A Possible Mechanism for Combined Chlorine and Bromine Catalyzed Destruction of Tropospheric Ozone in the Arctic, Geophys. Res. Lett., 22, 599-602, doi:10.1029/94GL03334, 1995.

Leaitch, W. R., Barrie, L. A., Bottenheim, J. W., Li, S. M., Shepson, P. B., Muthuramu, K., and Yokouchi, Y.: Airborne Observations Related to Ozone Depletion at Polar Sunrise, J. Geophys. Res., 99, 25499-25517, 1994

Lehrer, E., Hönninger, G., and Platt, U.: A one dimensional model study of the mechanism of halogen liberation and vertical transport in the polar troposphere, Atmos. Chem. Phys., 4, $2427-$ 2440, doi:10.5194/acp-4-2427-2004, 2004.

Liao, J., Huey, L. G., Tanner, D. J., Flocke, F. M., Orlando, J. J., Neuman, J. A., Nowak, J. B., Weinheimer, A. J., Hall, S. R., Smith, J. N., Fried, A., Staebler, R. M., Wang, Y., Koo, J. H., Cantrell, C. A., Weibring, P., Walega, J., Knapp, D. J., Shepson, P. B., and Stephens, C. R.: Observations of inorganic bromine $\left(\mathrm{HOBr}, \mathrm{BrO}\right.$, and $\left.\mathrm{Br}_{2}\right)$ speciation at Barrow, Alaska, in spring 2009, J. Geophys. Res., 117, D00R16, doi:10.1029/2011JD016641, 2012.

Liao, J., Huey, L. G., Liu, Z., Tanner, D. J., Cantrell, C. A., Orlando, J. J., Flocke, F. M., Shepson, P. B., Weinheimer, A. J., Hall, S. R., Ullmann, K., Beine, H. J., Wang, Y., Ingall, E. D., Stephens,
C. R., Hornbrook, R. S., Apel, E. C., Riemer, D., Fried, A., Mauldin III, R. L., Smith, J. N., Staebler, R. M., Neuman, J. A., and Nowak, J. B.: High levels of molecular chlorine in the Arctic atmosphere, Nature Geosci, 7, 91-94, doi:10.1038/ngeo2046, 2014.

Mahajan, A. S., Shaw, M., Oetjen, H., Hornsby, K. E., Carpenter, L. J., Kaleschke, L., Tian-Kunze, X., Lee, J. D., Moller, S. J., Edwards, P., Commane, R., Ingham, T., Heard, D. E., and Plane, J. M. C.: Evidence of reactive iodine chemistry in the Arctic boundary layer, J. Geophys. Res., 115, D20303, doi:10.1029/2009JD013665, 2010.

Martinez, M., Arnold, T., and Perner, D.: The role of bromine and chlorine chemistry for arctic ozone depletion events in $\mathrm{Ny}-$ Ålesund and comparison with model calculations, Ann. Geophys., 17, 941-956, doi:10.1007/s00585-999-0941-4, 1999.

Michalowski, B. A., Francisco, J. S., Li, S.-M., Barrie, L. A., Bottenheim, J. W., and Shepson, P. B.: A computer model study of multiphase chemistry in the Arctic boundary layer during polar sunrise, J. Geophys. Res., 105, 15131-15145, doi:10.1029/2000JD900004, 2000.

Miller, H. L., Weaver, A., Sanders, R. W., Arpag, K., and Solomon, S.: Measurements of arctic sunrise surface ozone depletion events at Kangerlussuaq, Greenland $\left(67^{\circ} \mathrm{N}, 51^{\circ} \mathrm{W}\right)$, Tellus B, 49, 496-509, doi:10.1034/j.1600-0889.49.issue5.6.x, 1997.

Moore, C. W., Obrist, D., Steffen, A., Staebler, R. M., Douglas, T. A., Richter, A., and Nghiem, S. V.: Convective forcing of mercury and ozone in the Arctic boundary layer induced by leads in sea ice, Nature, 506, 81-84, doi:10.1038/nature12924, 2014.

Morin, S., Hönninger, G. H., Staebler, R. M., and Bottenheim, J. W.: A high time resolution study of boundary layer ozone chemistry and dynamics over the Arctic Ocean near Alert, Nunavut, Geophys. Res. Lett., 32, L08809, doi:10.1029/2004GL022098, 2005.

Neuman, J. A., Nowak, J. B., Huey, L. G., Burkholder, J. B., Dibb, J. E., Holloway, J. S., Liao, J., Peischl, J., Roberts, J. M., Ryerson, T. B., Scheuer, E., Stark, H., Stickel, R. E., Tanner, D. J., and Weinheimer, A.: Bromine measurements in ozone depleted air over the Arctic Ocean, Atmos. Chem. Phys., 10, 6503-6514, doi:10.5194/acp-10-6503-2010, 2010.

Nghiem, S. V., Rigor, I. G., Richter, A., Burrows, J. P., Shepson, P. B., Bottenheim, J., Barber, D. G., Steffen, A., Latonas, J., Wang, F. Y., Stern, G., Clemente-Colon, P., Martin, S., Hall, D. K., Kaleschke, L., Tackett, P., Neumann, G., and Asplin, M. G.: Field and satellite observations of the formation and distribution of Arctic atmospheric bromine above a rejuvenated sea ice cover, J. Geophys. Res., 117, D00S05, doi:10.1029/2011JD016268, 2012.

Oltmans, S. J., Johnson, B. J., and Harris, J. M.: Springtime boundary layer ozone depletion at Barrow, Alaska: Meteorological influence, year-to-year variation, and long-term change, J. Geophys. Res., 117, D00R18, doi:10.1029/2011JD016889, 2012.

Piot, M. and von Glasow, R.: The potential importance of frost flowers, recycling on snow, and open leads for ozone depletion events, Atmos. Chem. Phys., 8, 2437-2467, doi:10.5194/acp-82437-2008, 2008.

Piot, M. and von Glasow, R.: Modelling the multiphase near-surface chemistry related to ozone depletions in polar spring, J. Atmos. Chem., 64, 77-105, doi:10.1007/s10874-010-9170-1, 2009.

Pöhler, D., Vogel, L., Frieß, U., and Platt, U.: Observation of halogen species in the Amundsen Gulf, Arctic, by active long-path 
differential optical absorption spectroscopy, Prog. Natl. Acad. Sci., 107, 6582-6587, doi:10.1073/pnas.0912231107, 2010.

Pratt, K. A., Custard, K. D., Shepson, P. B., Douglas, T. A., Pöhler, D., General, S., Zielcke, J., Simpson, W. R., Platt, U., Tanner, D. J., Huey, G. L., Carlsen, M., and Stirm, B. H.: Photochemical production of molecular bromine in Arctic surface snowpacks, Nature Geosci., 6, 351-356, doi:10.1038/ngeo1779, 2013.

Richter, A., Wittrock, F., Eisinger, M., and Burrows, J. P.: GOME observations of tropospheric $\mathrm{BrO}$ in northern hemispheric spring and summer 1997, Geophys. Res. Lett., 25, 2683-2686, 1998.

Ridley, B. A., Atlas, E. L., Montzka, D. D., Browell, E. V., Cantrell, C. A., Blake, D. R., Blake, N. J., Cinquini, L., Coffey, M. T., Emmons, L. K., Cohen, R. C., DeYoung, R. J., Dibb, J. E., Eisele, F. L., Flocke, F. M., Fried, A., Grahek, F. E., Grant, W. B., Hair, J. W., Hannigan, J. W., Heikes, B. J., Lefer, B. L., Mauldin, R. L., Moody, J. L., Shetter, R. E., Snow, J. A., Talbot, R. W., Thornton, J. A., Walega, J. G., Weinheimer, A. J., Wert, B. P., and Wimmers, A. J.: Ozone depletion events observed in the high latitude surface layer during the TOPSE aircraft program, J. Geophys. Res., 108, 8356, doi:10.1029/2001JD001507, 2003.

Rodgers, C. D.: Inverse Methods for Atmospheric Sounding: Theory and Practice, Series on Atmospheric, Oceanic, and Planetary Physics, edited by: Taylor, F. W., World Scientific Publishing, 46-50, 2000.

Saiz-Lopez, A., Mahajan, A. S., Salmon, R. A., Bauguitte, S. J. B., Jones, A. E., Roscoe, H. K., and Plane, J. M. C.: Boundary layer halogens in coastal Antarctica, Science, 317, 348-351, doi:10.1126/Science.1141408, 2007.

Salawitch, R. J., Canty, T., Kurosu, T., Chance, K., Liang, Q., da Silva, A., Pawson, S., Nielsen, J. E., Rodriguez, J. M., Bhartia, P. K., Liu, X., Huey, L. G., Liao, J., Stickel, R. E., Tanner, D. J., Dibb, J. E., Simpson, W. R., Donohoue, D., Weinheimer, A., Flocke, F., Knapp, D., Montzka, D., Neuman, J. A., Nowak, J. B., Ryerson, T. B., Oltmans, S., Blake, D. R., Atlas, E. L., Kinnison, D. E., Tilmes, S., Pan, L. L., Hendrick, F., Van Roozendael, M., Kreher, K., Johnston, P. V., Gao, R. S., Johnson, B., Bui, T. P., Chen, G., Pierce, R. B., Crawford, J. H., and Jacob, D. J.: A new interpretation of total column $\mathrm{BrO}$ during Arctic spring, Geophys. Res. Lett., 37, L21805, doi:10.1029/2010GL043798, 2010.

Schall, C. and Heumann, K. G.: GC determination of volatile organoiodine and organobromine compounds in Arctic seawater and air samples, Fresenius. J. Anal. Chem., 346, 717-722, doi:10.1007/bf00321279, 1993.

Seabrook, J. A., Whiteway, J., Staebler, R. M., Bottenheim, J. W., Komguem, L., Gray, L. H., Barber, D., and Asplin, M.: LIDAR measurements of Arctic boundary layer ozone depletion events over the frozen Arctic Ocean, J. Geophys. Res., 116, D00S02, doi:10.1029/2011JD016335, 2011.

Seabrook, J. A., Whiteway, J. A., Gray, L. H., Staebler, R., and Herber, A.: Airborne lidar measurements of surface ozone depletion over Arctic sea ice, Atmos. Chem. Phys., 13, 6023-6029, doi:10.5194/acp-13-6023-2013, 2013.

Sheridan, P. J., Schnell, R. C., Zoller, W. H., Carlson, N. D., Rasmussen, R. A., Harris, J. M., and Sievering, H.: Composition of Br-Containing Aerosols and Cases Related to Boundary-Layer Ozone Destruction in the Arctic, Atmos. Environ., Part A, 27, 2839-2849, 1993.
Simpson, W. R., Alvarez-Aviles, L., Douglas, T. A., Sturm, M., and Dominé, F.: Halogens in the coastal snow pack near Barrow, Alaska: Evidence for active bromine air-snow chemistry during springtime, Geophys. Res. Lett., 32, L04811, doi:10.1029/2004GL021748, 2005.

Simpson, W. R., Carlson, D., Hönninger, G., Douglas, T. A., Sturm, M., Perovich, D., and Platt, U.: First-year sea-ice contact predicts bromine monoxide $(\mathrm{BrO})$ levels at Barrow, Alaska better than potential frost flower contact, Atmos. Chem. Phys., 7, 621-627, doi:10.5194/acp-7-621-2007, 2007a.

Simpson, W. R., von Glasow, R., Riedel, K., Anderson, P., Ariya, P., Bottenheim, J., Burrows, J., Carpenter, L. J., Frieß, U., Goodsite, M. E., Heard, D., Hutterli, M., Jacobi, H. W., Kaleschke, L., Neff, B., Plane, J., Platt, U., Richter, A., Roscoe, H., Sander, R., Shepson, P., Sodeau, J., Steffen, A., Wagner, T., and Wolff, E.: Halogens and their role in polar boundary-layer ozone depletion, Atmos. Chem. Phys., 7, 4375-4418, doi:10.5194/acp-74375-2007, 2007b.

Solberg, S., Schmidbauer, N., Semb, A., Stordal, F., and Hov, O.: Boundary-layer ozone depletion as seen in the Norwegian Arctic in Spring, J. Atmos. Chem., 23, 301-332, doi:10.1007/Bf00055158, 1996.

Stephens, C. R.: Studies of tropospheric halogen radical chemistry during ozone and mercury depletion events in the Arctic, Ph.D., Chemistry, Purdue University, West Lafayette, IN, 356 pp., 2012.

Strong, C., Fuentes, J. D., Davis, R. E., and Bottenheim, J. W.: Thermodynamic attributes of Arctic boundary layer ozone depletion, Atmos. Environ., 36, 2641-2652, 2002.

Sumner, A. L., and Shepson, P. B.: Snowpack production of formaldehyde and its effect on the Arctic troposphere, Nature, 398, 230-233, 1999.

Sumner, A. L., Shepson, P. B., Grannas, A. M., Bottenheim, J. W., Anlauf, K. G., Worthy, D., Schroeder, W. H., Steffen, A., Dominé, F., Perrier, S., and Houdier, S.: Atmospheric chemistry of formaldehyde in the Arctic troposphere at Polar Sunrise, and the influence of the snowpack, Atmos. Environ., 36, 2553-2562, doi:10.1016/S1352-2310(02)00105-X, 2002.

Tang, T., and McConnell, J. C.: Autocatalytic release of bromine from Arctic snow pack during polar sunrise, Geophys. Res. Lett. 23, 2633-2636, doi:10.1029/96GL02572, 1996.

Tarasick, D. W. and Bottenheim, J. W.: Surface ozone depletion episodes in the Arctic and Antarctic from historical ozonesonde records, Atmos. Chem. Phys., 2, 197-205, doi:10.5194/acp-2197-2002, 2002

Theys, N., Van Roozendael, M., Hendrick, F., Yang, X., De Smedt, I., Richter, A., Begoin, M., Errera, Q., Johnston, P. V., Kreher, K., and De Mazière, M.: Global observations of tropospheric BrO columns using GOME-2 satellite data, Atmos. Chem. Phys., 11, 1791-1811, doi:10.5194/acp-11-1791-2011, 2011.

Thompson, A. M.: The Oxidizing Capacity of the Earths Atmosphere - Probable Past and Future Changes, Science, 256, $1157-$ 1165, 1992.

Thompson, C. R., Shepson, P. B., Liao, J., Huey, L. G., and Cantrell, C.: Bromine atom production and chain propagation during springtime Arctic ozone depletion events in Barrow, Alaska, in preparation, 2014.

Toyota, K., McConnell, J. C., Lupu, A., Neary, L., McLinden, C. A., Richter, A., Kwok, R., Semeniuk, K., Kaminski, J. W., Gong, S.-L., Jarosz, J., Chipperfield, M. P., and Sioris, C. E.: Analy- 
sis of reactive bromine production and ozone depletion in the Arctic boundary layer using 3-D simulations with GEM-AQ: inference from synoptic-scale patterns, Atmos. Chem. Phys., 11, 3949-3979, doi:10.5194/acp-11-3949-2011, 2011.

Tuckermann, M., Ackermann, R., Gölz, C., Lorenzen-Schmidt, H., Senne, T., Stutz, J., Trost, B., Unold, W., and Platt, U.: DOASobservation of halogen radical-catalysed arctic boundary layer ozone destruction during the ARCTOC-campaigns 1995 and 1996 in Ny-Ålesund, Spitsbergen, Tellus B, 49, 533-555, 1997.

Vogt, R., Crutzen, P. J., and Sander, R.: A mechanism for halogen release from sea-salt aerosol in the remote marine boundary layer, Nature, 383, 327-330, 1996.

Wennberg, P.: Atmospheric chemistry - Bromine explosion, Nature, 397, 299-301, doi:10.1038/16805, 1999.

Yang, X., Pyle, J. A., and Cox, R. A.: Sea salt aerosol production and bromine release: Role of snow on sea ice, Geophys. Res. Lett., 35, L16815, doi:10.1029/2008gl034536, 2008.
Yang, X., Pyle, J. A., Cox, R. A., Theys, N., and Van Roozendael, M.: Snow-sourced bromine and its implications for polar tropospheric ozone, Atmos. Chem. Phys., 10, 7763-7773, doi:10.5194/acp-10-7763-2010, 2010.

Zeng, T., Wang, Y. H., Chance, K., Browell, E. V., Ridley, B. A., and Atlas, E. L.: Widespread persistent near-surface ozone depletion at northern high latitudes in spring, Geophys. Res. Lett., 30, 2298, doi:10.1029/2003GL018587, 2003.

Zhou, X. L., Beine, H. J., Honrath, R. E., Fuentes, J. D., Simpson, W., Shepson, P. B., and Bottenheim, J. W.: Snowpack photochemical production of HONO: a major source of $\mathrm{OH}$ in the Arctic boundary layer in springtime, Geophys. Res. Lett., 28, 4087-4090, doi:10.1029/2001g1013531, 2001. 